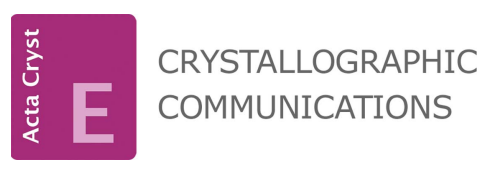

ISSN 2056-9890

Received 11 December 2018

Accepted 7 January 2019

Edited by L. Van Meervelt, Katholieke Universiteit Leuven, Belgium

Keywords: crystal structure; hydrogen bonding; Hirshfeld analysis; intermolecular interactions; ammonium carboxylate salts.

CCDC references: 1889253; 1889252

Supporting information: this article has supporting information at journals.iucr.org/e

\section{The crystal structures of benzylammonium phenyl- acetate and its hydrate}

\author{
David Hess $^{\mathrm{a} *}$ and Peter Mayer ${ }^{\mathrm{b}}$
}

anstitut Laue-Langevin, 71 Avenue des Martyrs, 38000 Grenoble, France, and ${ }^{\mathbf{b}}$ Ludwig-Maximilians-Universität, Department Chemie, Butenandtstrasse, 5-13, 81377 München, Germany. *Correspondence e-mail: hessd@ill.fr

The title compounds benzylammonium phenylacetate, $\mathrm{C}_{7} \mathrm{H}_{10} \mathrm{~N}^{+} \cdot \mathrm{C}_{8} \mathrm{H}_{7} \mathrm{O}_{2}{ }^{-}$(1), and its monohydrate, $\mathrm{C}_{7} \mathrm{H}_{10} \mathrm{~N}^{+} \cdot \mathrm{C}_{8} \mathrm{H}_{7} \mathrm{O}_{2}{ }^{-} \cdot \mathrm{H}_{2} \mathrm{O}$ (2), can be obtained by evaporating methanolic solutions containing equimolar amounts of benzylamine and phenylacetic acid in the absence and presence of water, respectively. $\mathrm{N}-$ $\mathrm{H}$. . O hydrogen bonds in the crystal structure of $\mathbf{1}$ lead to the formation of hydrophilic channels running along the $b$-axis direction. The hydrogen-bonding system is best described by fused $R_{4}^{3}(10)$ ring patterns, often observed in ammonium carboxylate salts. In $\mathbf{2}$, the presence of the crystal water leads to the formation of a two-dimensional hydrogen-bonding network. The benzyl moieties in $\mathbf{1}$ and $\mathbf{2}$ form hydrophobic layers in the crystal structures with the aromatic rings adopting edge-to-face arrangements.

\section{Chemical context}

Many proteins can self-assemble into insoluble aggregates, socalled amyloids, with a high content of $\beta$-strands. Amyloid fibrils are qualitatively similar for different proteins, with filaments of a few nanometers in diameter that can grow up to several micrometers in length (McManus et al., 2016). The amyloid state of proteins is linked to various human diseases, e.g. Alzheimer's disease (Eisenberg \& Jucker, 2012). Besides proteins, oligopeptides (Ozbas et al., 2004) down to simple dipeptides (Reches \& Gazit, 2003) and even the amino acid phenylalanine (Mossou et al., 2014; Do et al., 2015) can also self-assemble into stable nanofilaments in aqueous solution. Apart from the obvious link to amyloid diseases, such structures are also interesting for technical applications (Gazit, 2007; Manna et al., 2015). Hydrogen bonds between ammonium and carboxylate groups, as well as the presence of hydrophobic residues (e.g. aromatic residues) play an important role in the formation of self-assembled structures of (di)peptides or amino acids (Görbitz, 2010; Mossou et al., 2014; Reches \& Gazit, 2003). Similarly, the packing motifs of ammonium carboxylate salts are governed by the formation of hydrogen-bonded networks between the ammonium and carboxylate groups, as well as the nature of the residues of the ammonium and carboxylate residues (Kinbara et al., 1996; Odendal et al., 2010).
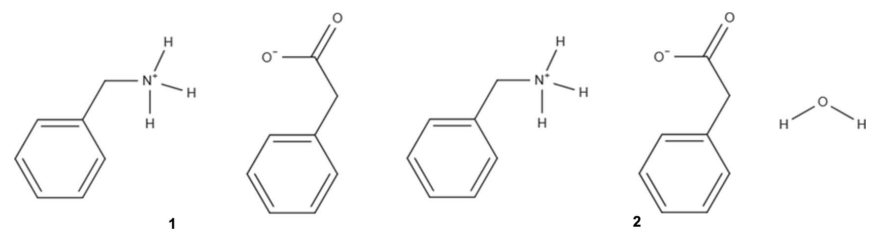
Table 1

Contributions of close intermolecular contacts to the Hirshfeld surface areas of the molecules in $\mathbf{1}$ and $\mathbf{2}$.

\begin{tabular}{|c|c|c|c|c|c|c|c|c|}
\hline Compound & molecule & $\mathrm{O} \cdots \mathrm{H}$ & $\mathrm{H} \cdots \mathrm{O}$ & $\mathrm{C} \cdots \mathrm{H}$ & $\mathrm{H} \cdots \mathrm{C}$ & $\mathrm{C} \cdots \mathrm{O}$ & $\mathrm{O} \cdots \mathrm{C}$ & $\mathrm{H} \cdots \mathrm{H}$ \\
\hline \multirow[t]{2}{*}{1} & benzylammonium & 0.0 & 15.8 & 13.6 & 13.8 & 1.3 & 0.0 & 55.5 \\
\hline & phenylacetate & 21.5 & 4.1 & 16.9 & 6.6 & 0.0 & 0.7 & 50.2 \\
\hline \multirow[t]{2}{*}{2} & benzylammonium & 0.0 & 13.2 & 15.6 & 11.4 & 0.0 & 0.0 & 59.7 \\
\hline & water & 30.5 & 22.4 & 0.0 & 1.8 & 0.0 & 0.0 & 44.9 \\
\hline
\end{tabular}

Herein, we report the crystal structures of benzylammonium phenylacetate and its hydrate. Both show a similar crystal packing to the zwitterionic form of L-phenylalanine reported by Mossou et al. (2014). This resemblance raises the question of whether a system such as benzylammonium phenylacetate is also capable of forming nanofilaments.

\section{Structural commentary}

Benzylammonium phenylacetate (1) crystallizes in the monoclinic space group $C 2 / c$ and its hydrate (2) in the monoclinic space group $P 2_{1} / n$. The asymmetric units of $\mathbf{1}$ and its hydrate $\mathbf{2}$ are shown in Fig. 1. In compound 1, the ammonium group of the benzylammonium is orientated almost perpendicular to the phenyl ring $\left[90.2(2)^{\circ}\right]$, while the carboxylate group of the phenylacetate adopts a torsion angle of $-70.2(4)^{\circ}$, while in the hydrate 2 the torsion angles between the phenyl rings and the functional groups are $72.4(4)$ and $54.4(4)^{\circ}$ for the phenylacetate and benzylammonium, respectively.

\section{Supramolecular features}

\subsection{Crystal packing}

The crystal packing of benzylammonium phenylacetate (1) consists of columns arranged around the twofold screw axis along $b$ (Fig. 2). These columns are composed of hydrophilic channels, formed by the ammonium and carboxylate groups, surrounded by a shell made up by the phenyl moieties. The crystal packing of the hydrate (2) consists of hydrophilic and hydrophobic layers alternating along the $c$-axis direction, as shown in Fig. 3. The hydrophilic layer is composed of the water molecules, the ammonium and the carboxylate groups. (a)

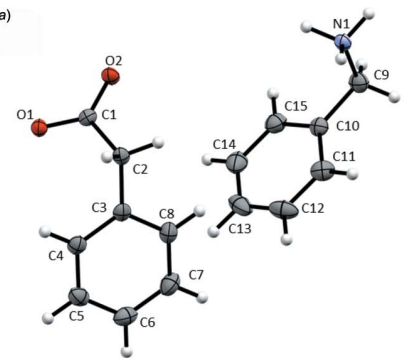

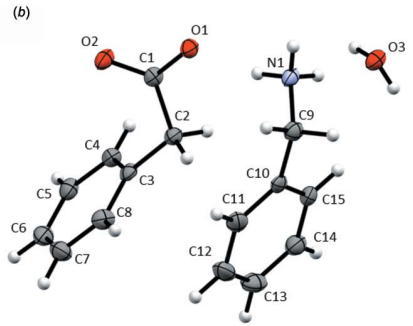

Figure 1

ORTEP representation of the asymmetric unit in $(a) \mathbf{1}$ and $(b) \mathbf{2}(50 \%$ probability ellipsoids).

\subsection{Intermolecular contacts and Hirshfeld analysis}

We used CrystalExplorer17 to analyse the Hirshfeld surfaces of the molecules in the crystal structures of $\mathbf{1}$ and $\mathbf{2}$ and to quantify intermolecular contacts between them (Turner et al., 2017; McKinnon et al., 2007). Table 1 summarizes the relative contributions to the Hirshfeld surface areas for the intermolecular contacts found in the molecules of $\mathbf{1}$ and $\mathbf{2}$.
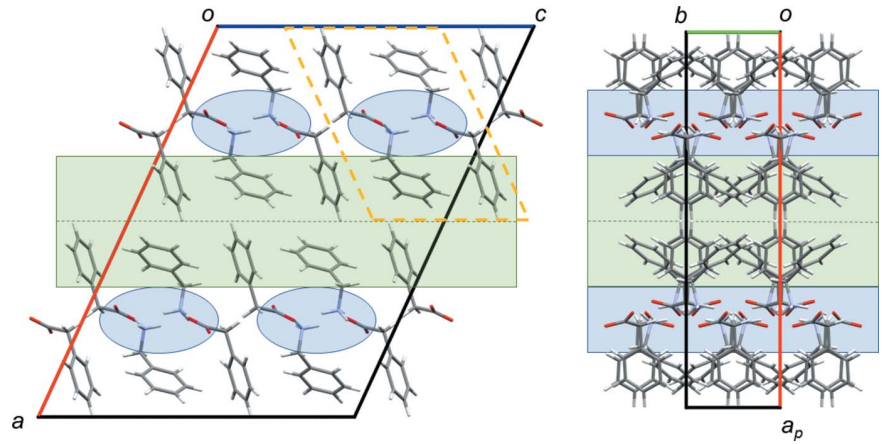

Figure 2

Crystal packing of $\mathbf{1}$ with views along the $b$ axis (left) and along the $c$ axis (right). Yellow dotted lines mark a column arranged around a twofold screw axis. Hydrophilic areas are highlighted in blue, hydrophobic areas in green.
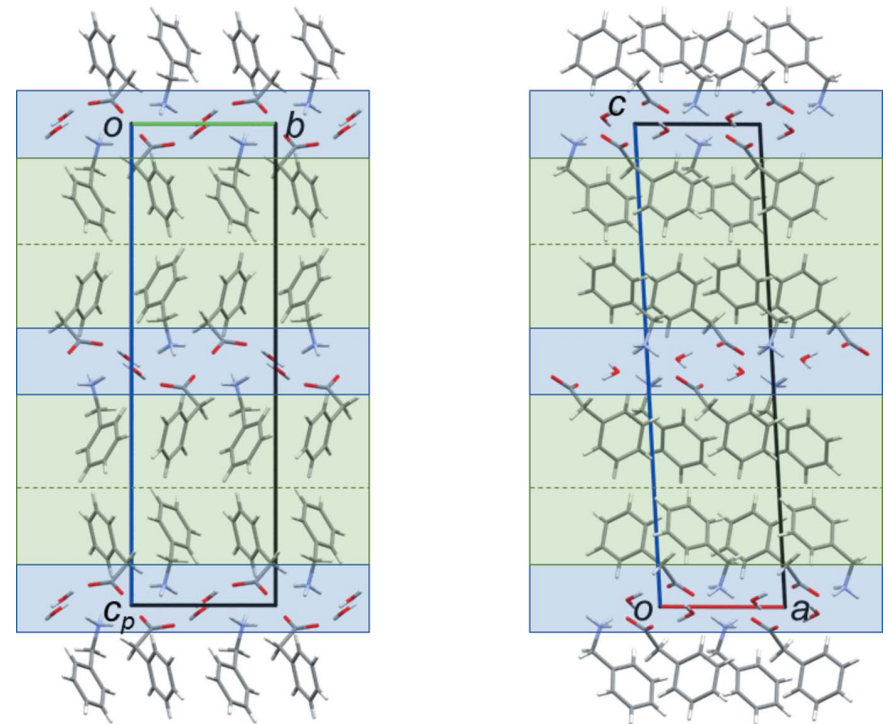

Figure 3

Crystal packing of 2 with views along the $a$ axis (left) and along the $b$ axis (right). Hydrophilic areas are highlighted in blue, hydrophobic areas in green. 
There are three main groups of (inner $\cdots$ outer) intermolecular contacts that can be found on the Hirshfeld surfaces, namely $\mathrm{O} \cdots \mathrm{H} / \mathrm{H} \cdots \mathrm{O}, \mathrm{C} \cdots \mathrm{H} / \mathrm{H} \cdots \mathrm{C}$ and $\mathrm{H} \cdots \mathrm{H}$ intermolecular contacts. Fig. 4 shows the fingerprint plots of the benzylammonium and phenylacetate molecules in $\mathbf{1}$ and 2, highlighting the $\mathrm{O} \cdots \mathrm{H} / \mathrm{H} \cdots \mathrm{O}$ and $\mathrm{C} \cdots \mathrm{H} / \mathrm{H} \cdots \mathrm{C}$ contacts.

Mapping the Hirshfeld surfaces with different functions is a helpful tool for visualizing the nature of those intermolecular contacts. For example, the normalized contact distance $d_{\text {norm }}$ mapped on the Hirshfeld surface using a red-white-blue colour scheme indicates distances shorter, around or greater than the van der Waals separation distances, respectively. The normalized contact distance is defined by the following equation

$$
d_{n o r m}=\frac{d_{i}-r_{d}^{v d w}}{r_{i}^{v d w}}+\frac{d_{e}-r_{d}^{v d w}}{r_{e}^{r d w}}
$$

\section{1 benzylammonium 2}

(a)

(b)

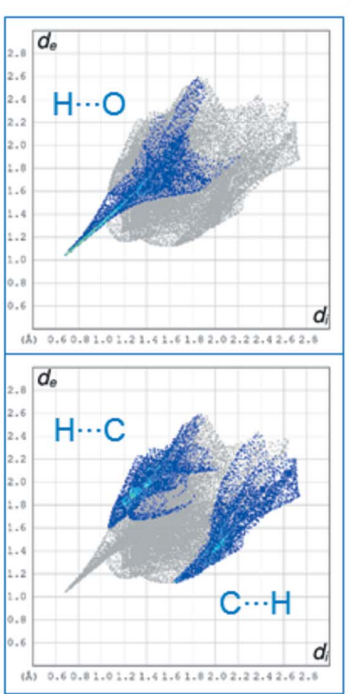

1

(c)

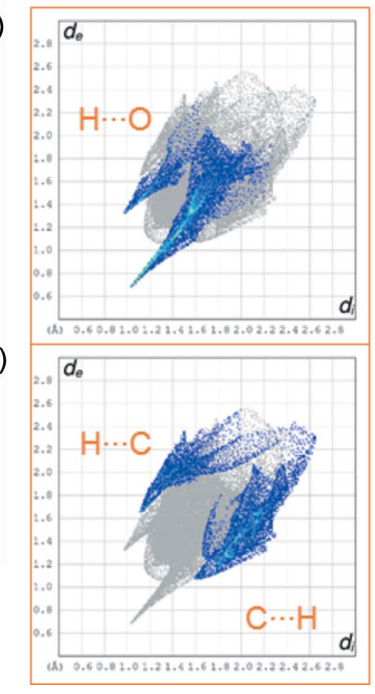

(d)

$(f)$

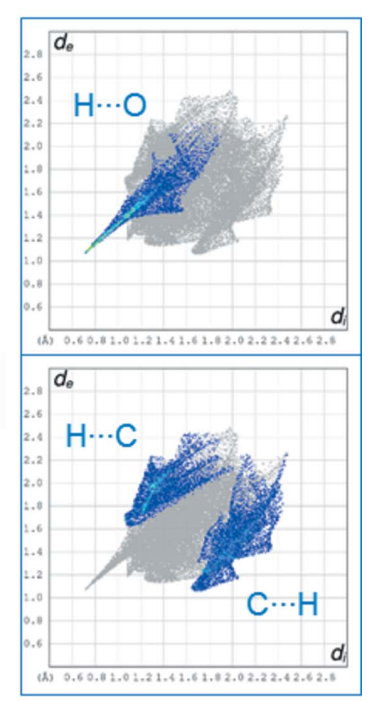

2

(g)

(h)

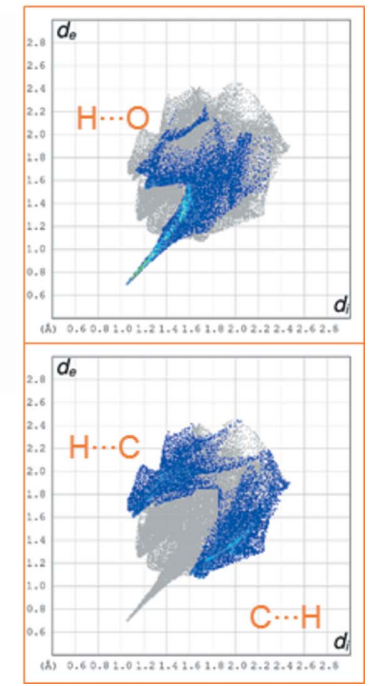

Figure 4

Comparison of the fingerprint plots of the benzylammonium and phenylacetate molecules in $\mathbf{1}$ and $\mathbf{2}$, highlighting $\mathrm{O} \cdots \mathrm{H} / \mathrm{H} \cdots \mathrm{O}$ and $\mathrm{C} \cdots \mathrm{H} / \mathrm{H} \cdots \mathrm{C}$ contacts. $d_{\mathrm{i}}$ and $d_{\mathrm{e}}$ are plotted in $\AA$ on the $x$ - and $y$-axis, respectively. where $d_{i}$ and $d_{e}$ are the distances to the nearest atoms inside and outside the surface and $r^{v d w}$ is the van der Waals radius of the appropriate atom internal or external to the surface (McKinnon et al., 2007). Fig. 5 shows the benzylammonium and phenylacetate molecules in $\mathbf{1}$ with $d_{\text {norm }}$ mapped. A number of contacts with distances below the sum of the van der Waals radius can directly be identified by red spots. The most intense ones $\left(A / A^{\prime}, B / B^{\prime}, C / C^{\prime}\right.$ in Fig. 5) can be attributed to $\mathrm{N}-\mathrm{H} \cdots \mathrm{O}$ hydrogen bonds between the benzylammonium and phenylacetate molecules. The remaining spots are due to non-classical $\mathrm{C}-\mathrm{H} \cdots \mathrm{O}$ hydrogen bonds among the phenylacetate molecules $\left(D / D^{\prime}, E / E^{\prime}\right.$ in Fig. 5) and an aliphatic C$\mathrm{H} \cdots \pi$ interaction between benzylammonium and phenylacetate $\left(F / F^{\prime}\right.$ in Fig. 5). Fig. 6 shows the normalized contact distance $d_{\text {norm }}$ mapped on the Hirshfeld surface of the molecules in 2, highlighting the $\mathrm{N}-\mathrm{H} \cdots \mathrm{O}\left(C / C^{\prime}, D / D^{\prime}\right.$ and $\left.E / E^{\prime}\right)$ and $\mathrm{O}-\mathrm{H} \cdots \mathrm{O}\left(A / A^{\prime}, B / B^{\prime}\right)$ hydrogen bonds as the primary intermolecular interactions, followed by the non-classical C$\mathrm{H} \cdots \mathrm{O}$ hydrogen bonds $\left(F / F^{\prime}\right.$ and $\left.G / G^{\prime}\right)$. Two further close contacts of the type $\mathrm{C}-\mathrm{H} \cdots \mathrm{C}\left(H / H^{\prime}\right.$ and $\left.I / I^{\prime}\right)$ can be identified.
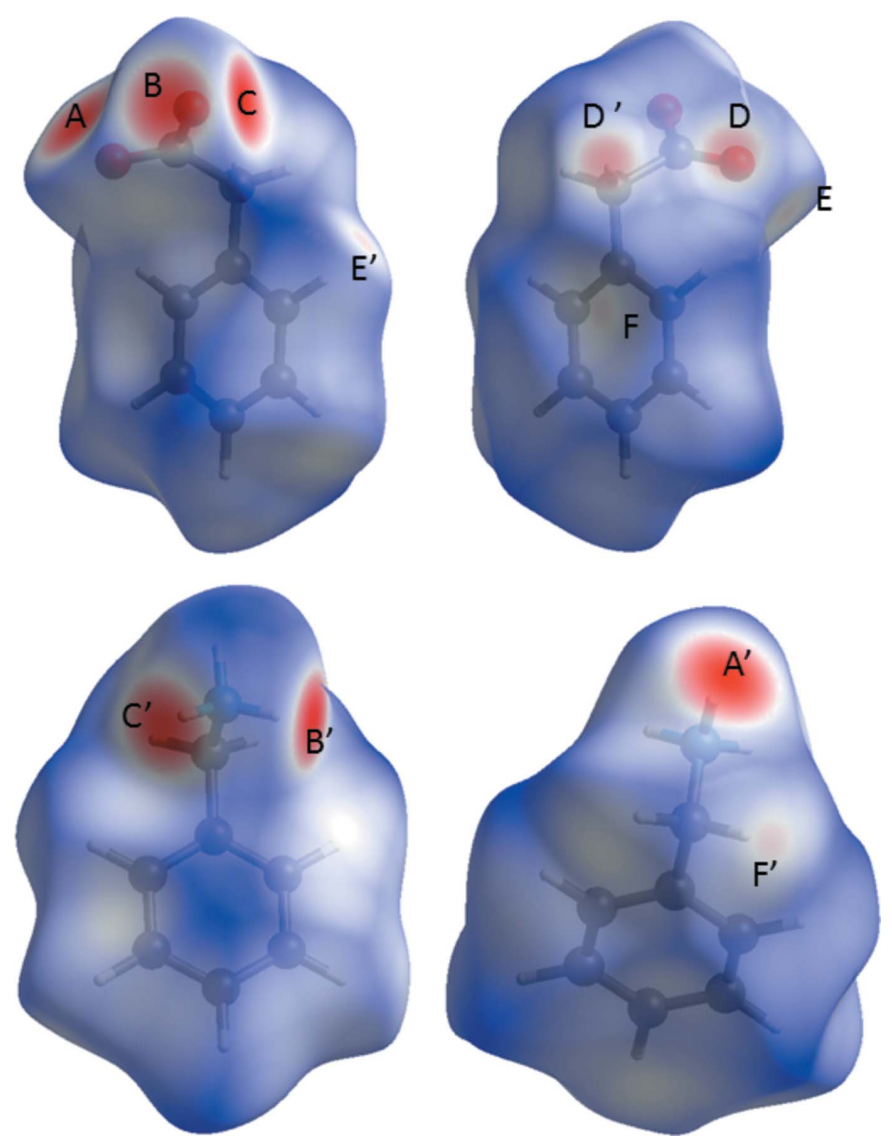

Figure 5

Hirshfeld surfaces of benzylammonium (bottom) and phenylacetate (top) molecules in 1 mapped with $d_{\text {norm }}$. Red spots indicate contact areas shorter than the van der Waals separation. Those contacts can be attributed to the following intermolecular interactions: $\mathrm{N} 1-\mathrm{H} 11 \cdots \mathrm{O} 1$ $\left(A / A^{\prime}\right), \mathrm{N}-\mathrm{H} 13 \cdots \mathrm{O} 2\left(B / B^{\prime}\right), \mathrm{N}-\mathrm{H} 12 \cdots \mathrm{O} 2\left(C / C^{\prime}\right), \mathrm{C} 2-\mathrm{H} 2 B \cdots \mathrm{O} 1(D /$ $\left.D^{\prime}\right), \mathrm{C} 8-\mathrm{H} 8 \cdots \mathrm{O} 1\left(E / E^{\prime}\right)$, and $\mathrm{C} 9-\mathrm{H} 9 B \cdots \pi\left(F / F^{\prime}\right)$. The map ranges from -0.6825 to 1.3335 a.u. for phenylacetate and -0.6822 to 1.4269 a.u. for benzylammonium. 

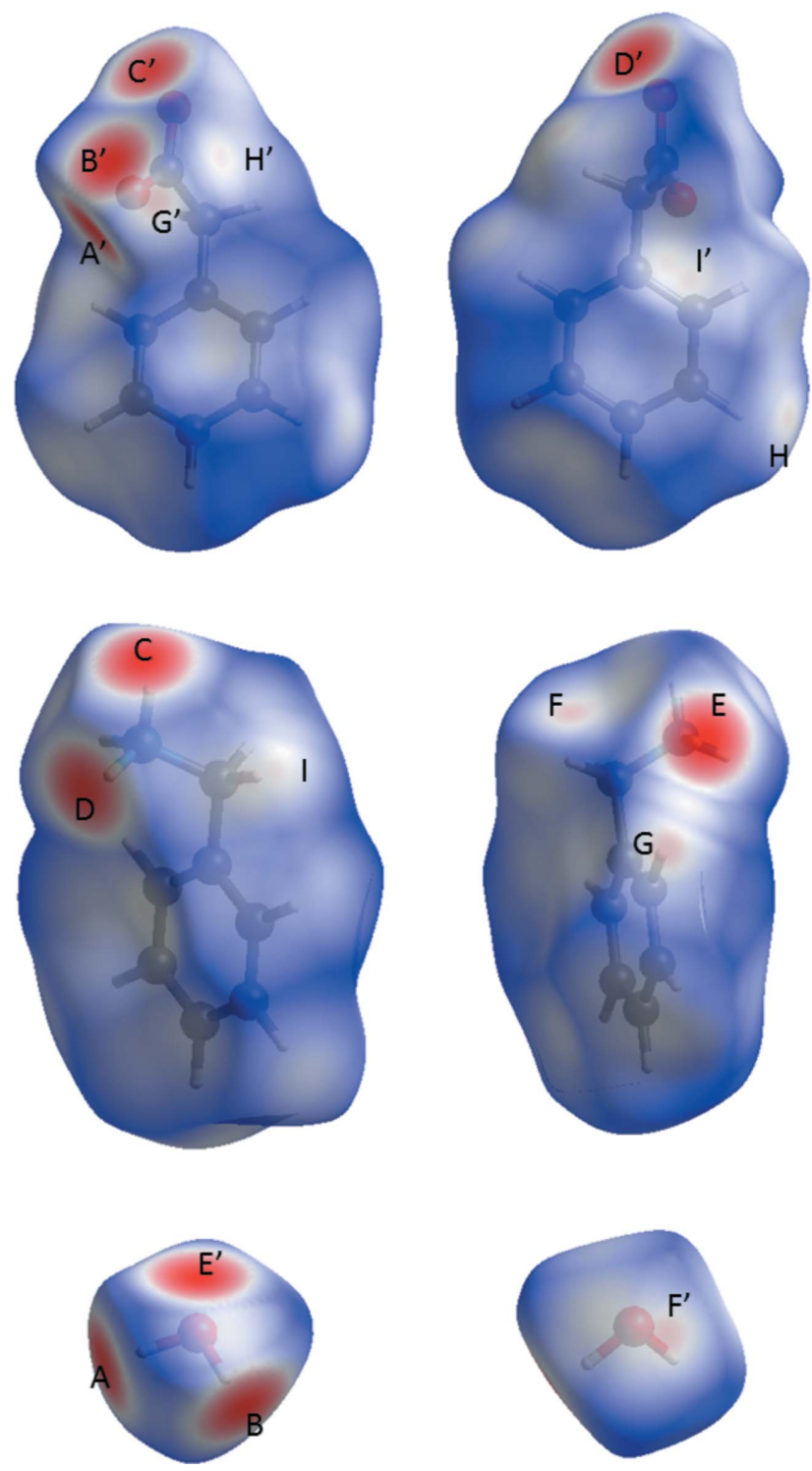

Figure 6

Hirshfeld surfaces of phenylacetate (top), benzylammonium (middle) and water (bottom) molecules in $\mathbf{2}$ mapped with $d_{\text {norm }}$. Red spots indicate contact areas shorter than the van der Waals separation. Contacts can be attributed to the following intermolecular interactions: $\mathrm{O} 3-\mathrm{H} 32 \cdots \mathrm{O} 2$ $\left(A / A^{\prime}\right), \mathrm{O} 3-\mathrm{H} 31 \cdots \mathrm{O} 2\left(B / B^{\prime}\right), \mathrm{N}-\mathrm{H} 12 \cdots \mathrm{O} 1\left(C / C^{\prime}\right), \mathrm{N}-\mathrm{H} 11 \cdots \mathrm{O} 1(D /$ $\left.D^{\prime}\right), \mathrm{N}-\mathrm{H} 13 \cdots \mathrm{O} 3\left(E / E^{\prime}\right), \mathrm{C} 9-\mathrm{H} 9 B \cdots \mathrm{O} 3\left(F / F^{\prime}\right), \mathrm{C} 15-\mathrm{H} 15 \cdots \mathrm{O} 2(G /$ $\left.G^{\prime}\right), \mathrm{C} 5-\mathrm{H} 5 \cdots \mathrm{C} 1\left(H / H^{\prime}\right)$ and $\mathrm{C} 9-\mathrm{H} 9 A \cdots \mathrm{C} 4\left(I / I^{\prime}\right)$. The map ranges from -0.6666 to 1.2024 a.u. for phenylacetate, -0.6268 to 1.1600 a.u. for benzylammonium and -0.6680 to 1.0780 a.u. for water.

Fig. 4 shows the fingerprint plots of the benzylammonium and phenylacetate molecules in $\mathbf{1}$ and $2 . \mathrm{O} \cdots \mathrm{H} / \mathrm{H} \cdots \mathrm{O}$ contacts can be attributed mainly to classical and non-classical, i.e. $\mathrm{C}-\mathrm{H} \cdots \mathrm{O}$, hydrogen bonds. Naturally no $\mathrm{O} \cdots \mathrm{H}$ contacts, but only $\mathrm{H}$... O contacts are found on the Hirshfeld surface of the benzylammonium molecules, resulting in a single spike (i.e. $\mathrm{N}-\mathrm{H} \cdots \mathrm{O}$ hydrogen bonds) highlighted in the fingerprint plots $(a)$ and $(e)$ in Fig. 4. The phenylacetate molecules can act as hydrogen-bond acceptors via their oxygen atoms (i.e. $\mathrm{O} \cdot \mathrm{H}$ contacts), visible through the intense spike in the fingerprint plots $(c)$ and $(d)$ in Fig. 4. In addition, $\mathrm{H} \cdots \mathrm{O}$
Table 2

Hydrogen-bond geometry $\left(\AA,^{\circ}\right)$ for $\mathbf{1}$.

$C g 1$ is the centroid of the $\mathrm{C} 3-\mathrm{C} 8$ ring.

\begin{tabular}{lllll}
\hline$D-\mathrm{H} \cdots A$ & $D-\mathrm{H}$ & $\mathrm{H} \cdots A$ & $D \cdots A$ & $D-\mathrm{H} \cdots A$ \\
\hline $\mathrm{N} 1-\mathrm{H} 11 \cdots \mathrm{O} 1^{\mathrm{i}}$ & $0.97(2)$ & $1.77(2)$ & $2.7177(19)$ & $165(2)$ \\
$\mathrm{N} 1-\mathrm{H} 12 \cdots \mathrm{O} 2^{\mathrm{ii}}$ & $1.01(2)$ & $1.73(2)$ & $2.7306(19)$ & $170.1(18)$ \\
$\mathrm{N} 1-\mathrm{H} 13 \cdots 2^{\mathrm{iii}}$ & $0.95(3)$ & $1.85(3)$ & $2.7938(19)$ & $174(2)$ \\
$\mathrm{C} 2-\mathrm{H} 2 B \cdots \mathrm{O} 1^{\mathrm{i}}$ & 0.99 & 2.40 & $3.375(2)$ & 169 \\
$\mathrm{C} 8-\mathrm{H} 8 \cdots 1^{\mathrm{iii}}$ & 0.95 & 2.63 & $3.539(2)$ & 161 \\
$\mathrm{C} 9-\mathrm{H} 9 \cdots C g 1^{\mathrm{v}}$ & 0.95 & 2.92 & $3.877(2)$ & 163 \\
\hline
\end{tabular}

Symmetry codes: (i) $-x+\frac{1}{2}, y+\frac{3}{2},-z+\frac{1}{2}$; (ii) $-x+\frac{1}{2}, y+\frac{1}{2},-z+\frac{1}{2}$; (iii) $x, y+1, z$; (iv) $-x+\frac{1}{2},-y-\frac{1}{2},-z+1 ;$ (v) $x,-y+1, z-\frac{1}{2}$.

Table 3

Hydrogen-bond geometry $\left(\AA,^{\circ}\right)$ for 2 .

\begin{tabular}{lllll}
\hline$D-\mathrm{H} \cdots A$ & $D-\mathrm{H}$ & $\mathrm{H} \cdots A$ & $D \cdots A$ & $D-\mathrm{H} \cdots A$ \\
\hline $\mathrm{O} 3-\mathrm{H} 32 \cdots \mathrm{O} 2^{\mathrm{i}}$ & $0.83(4)$ & $1.90(4)$ & $2.728(4)$ & $175(4)$ \\
$\mathrm{O}^{\mathrm{ii}}-\mathrm{H} 31 \cdots \mathrm{O} 2^{\mathrm{i}}$ & $0.97(4)$ & $1.81(4)$ & $2.771(4)$ & $169(3)$ \\
$\mathrm{N} 1-\mathrm{H} 11 \cdots \mathrm{O} 1$ & $0.89(4)$ & $1.92(4)$ & $2.791(4)$ & $168(4)$ \\
$\mathrm{N} 1-\mathrm{H} 12 \cdots \mathrm{O} 1^{\mathrm{iii}}$ & $0.90(4)$ & $1.96(4)$ & $2.805(4)$ & $157(4)$ \\
$\mathrm{N} 1-\mathrm{H} 13 \cdots \mathrm{O} 3$ & $0.94(4)$ & $1.87(4)$ & $2.809(4)$ & $170(3)$ \\
$\mathrm{C} 9-\mathrm{H} 9 B \cdots \mathrm{O}^{\text {iv }}$ & 0.99 & 2.51 & $3.196(4)$ & 126 \\
$\mathrm{C} 15-\mathrm{H} 15 \cdots \mathrm{O} 2$ & & & \\
\end{tabular}

Symmetry codes: (i) $x, y-1, z$; (ii) $-x+1,-y+1,-z+1$; (iii) $-x,-y+1,-z+1$; (iv) $-x,-y,-z+1$.

contacts are observed for the phenylacetate molecules in $\mathbf{1}$ and 2. Such contacts can come from non-classical $\mathrm{C}-\mathrm{H} \cdots \mathrm{O}$ hydrogen bonds, where the phenylacetate acts as a donor. However, a spike in the fingerprint plots indicating short hydrogen-oxygen distances is only observed for phenylacetate in compound 1 (Fig. 4c) and not in compound 2 (Fig. 4g), implying that $\mathrm{C}-\mathrm{H} \cdots \mathrm{O}$ hydrogen bonds may be more important in 1 than in the hydrate 2. C $\cdots \mathrm{H} / \mathrm{H} \cdots \mathrm{C}$ intermolecular contacts can arise from close ring contacts of the phenyl rings in the hydrophobic layers, but also from aliphatic $\mathrm{C}-\mathrm{H} \cdots \pi$ interactions. An examination of the crystal packings in Figs. 2 and 3 reveals that the phenyl rings are not stacked in a planar, parallel fashion. This is consistent with the absence of C. . C intermolecular contacts, which would be expected in such a case (Turner et al., 2017). $\mathrm{O} \cdots \mathrm{H} / \mathrm{H} \cdots \mathrm{O}$ and $\mathrm{C} \cdots \mathrm{H} /$ $\mathrm{H}$... C contacts will be discussed in more detail below.

3.2.1. $\mathrm{O} \cdots \mathrm{H} / \mathrm{H} \cdots \mathrm{O}$ intermolecular contacts. As mentioned above, $\mathrm{O} \cdots \mathrm{H} / \mathrm{H} \cdots \mathrm{O}$ contacts can be attributed mainly to classical and non-classical hydrogen bonds. In compound $\mathbf{1}$, intermolecular oxygen-hydrogen contacts amount to about 16 and $26 \%$ of the Hirshfeld surface area for the benzylammonium and phenylacetate molecules, respectively. In the hydrate $\mathbf{2}$, the values are about 13 and $27 \%$, respectively. The hydrogen-bond parameters for $\mathbf{1}$ and $\mathbf{2}$ are summarized in Tables 2 and 3, respectively. In 1, the classical hydrogenbonding system involves the benzylammonium molecule as a donor and the phenylacetate molecule as an acceptor for $\mathrm{N}-$ $\mathrm{H}$... O hydrogen bonds. In 2, this system is extended by the presence of the water molecule of crystallization acting as a hydrogen-bond donor and acceptor at the same time. The hydrogen-bonding system in $\mathbf{1}$ can be described by chain patterns corresponding to a second level graph set 


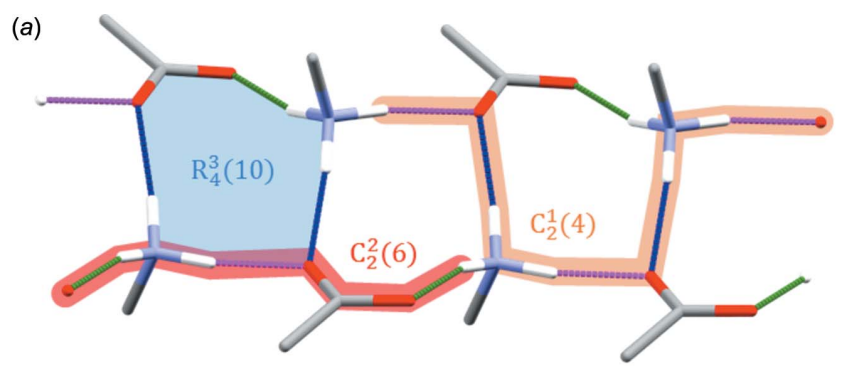

(b)

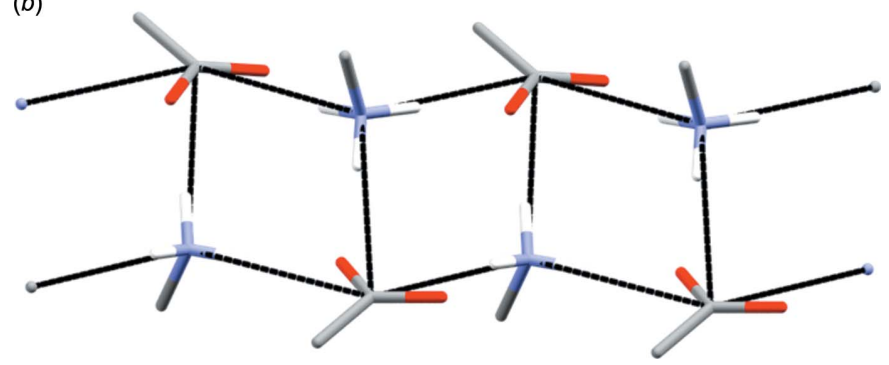

Figure 7

(a) Hydrogen-bonding patterns in $\mathbf{1}$. A section of the $C_{2}^{1}(4)$ chain pattern is highlighted in orange, and a section of one of the two possible $C_{2}^{2}(6)$ chain patterns is highlighted in red. The $R_{4}^{3}(10)$ ring pattern is highlighted in blue. Colour code for the hydrogen bonds: $\mathrm{N} 1-\mathrm{H} 11 \cdots \mathrm{O} 1$ green, $\mathrm{N} 1-$ $\mathrm{H} 12 \cdots \mathrm{O} 2$ magenta, $\mathrm{N} 1-\mathrm{H} 13 \cdots \mathrm{O} 2$ blue. (b) Cation-anion ladder motif in $\mathbf{1}$ formed by the repetition of benzylammonium-phenylacetate pairs. Phenyl rings and $\mathrm{CH}_{2} \mathrm{H}$ atoms are omitted for clarity.

$C_{2}^{2}(6) C_{2}^{2}(6) C_{2}^{1}(4)$ (Bernstein et al., 1995). However, a more obvious feature is the ring structure denoted by a third level pattern $R_{4}^{3}(10)$ (Fig. $\left.7 a\right)$.

The $R_{4}^{3}(10)$ ring pattern is a common feature of ammonium carboxylate salts and has been described earlier (Kinbara et al., 1996). Related to this particular ring pattern is an electrostatic ladder motif. Two benzylammonium-phenylacetate (cation-anion) pairs form a dimeric ring, which associates with further cation-anion pairs to form a ladder running along the twofold screw axis of the crystal (Fig. $7 b$ ). Such a motif is common in ammonium carboxylate salts (Odendal et al., 2010). Evidently, the presence of crystal water in 2 leads to a change in the hydrogen-bonding system compared to $\mathbf{1}$. Going from 1 to 2, water replaces one of the $\mathrm{N}-\mathrm{H} \cdots \mathrm{O}$ bonds between benzylammonium and phenylacetate. Consequently, the fused $R_{4}^{3}(10)$ pattern in $\mathbf{1}$ is disrupted and two alternating $R_{4}^{2}(8)$ patterns bridged by a carboxylate group are formed (Fig. 8a). Those rows are then connected among each other via the freed $\mathrm{N}-\mathrm{H}$ donor group of the benzylammonium molecules and water molecules as acceptors to form a twodimensional hydrogen-bonding network network (Fig. 8b). Non-classical hydrogen bonds in $\mathbf{1}$ are formed exclusively between the phenylacetate molecules, forming fused $R_{2}^{2}(8)$ and $R_{2}^{2}(10)$ ring patterns alternating along the columns around the twofold screw axis along $b$. The hydrogen-bonding system is shown in Fig. $9 a$. In $\mathbf{2}$, the benzylammonium molecule acts as a donor for two discrete non-classical $\mathrm{C}-\mathrm{H} \cdots \mathrm{O}$ hydrogen bonds (Fig. $9 b$ ), one with the water molecule of crystallization as acceptor $(\mathrm{C} 9-\mathrm{H} 9 \mathrm{~B} \cdots \mathrm{O} 3)$ and a second one with an oxygen atom of the carboxylate group of phenylacetate

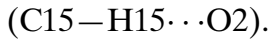
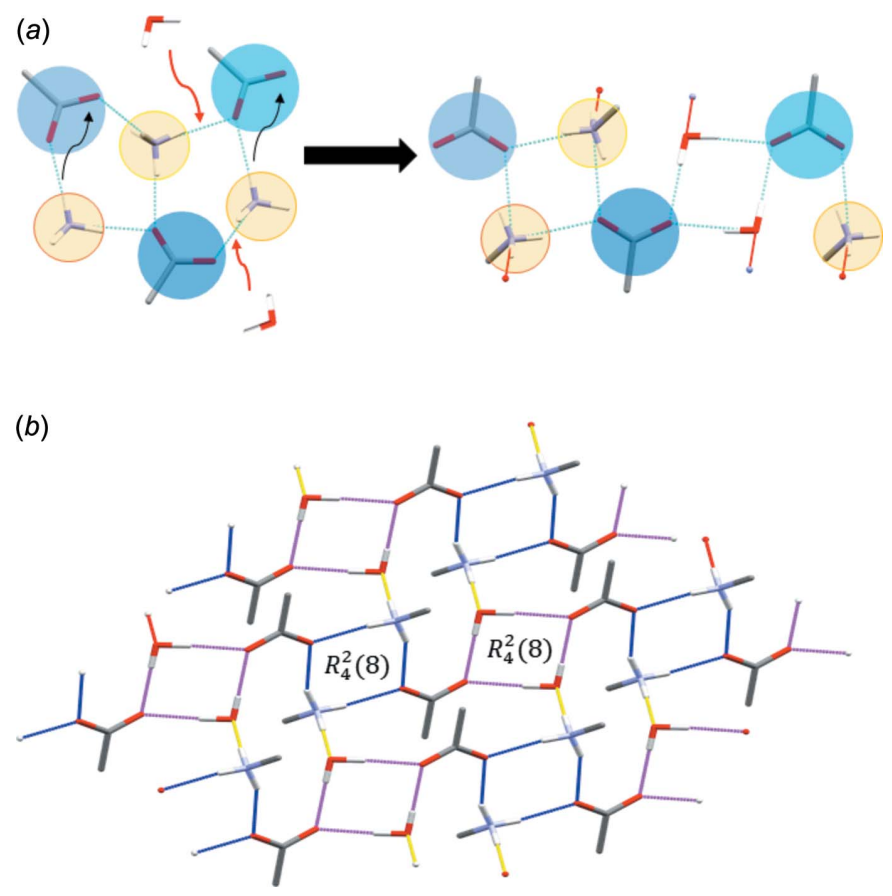

Figure 8

(a) Transformation of the hydrogen-bonding network in $\mathbf{1}$ to the network found in $\mathbf{2}$ by incorporation of crystal water. (b) The two-dimensional hydrogen-bonding network in 2 . Rows of alternating $R_{4}^{2}(8)$ motifs (hydrogen bonds highlighted in blue and magenta, respectively) are connected via discrete $\mathrm{N}-\mathrm{H} \cdots \mathrm{O}$ hydrogen bonds (highlighted in yellow). Phenyl rings and $\mathrm{CH}_{2} \mathrm{H}$ atoms are omitted for clarity.

3.2.2. C...H/H...C intermolecular contacts. Carbonhydrogen intermolecular contacts contribute to around one quarter of the Hirshfeld surface areas of the benzylammonium and phenylacetate molecules in both $\mathbf{1}$ and 2. As explained above, those contacts are mainly due to close contacts between the phenyl rings in the hydrophobic layers of the crystal packing, but also to (aliphatic) $\mathrm{C}-\mathrm{H} \cdots \pi$ interactions. An automated search using PLATON (Spek, 2009) revealed four short ring interactions and one aliphatic $\mathrm{C}-\mathrm{H} \cdots \pi$ interaction in 1 (Fig. 10) and six short ring interactions and one aliphatic $\mathrm{C}-\mathrm{H} \cdots \pi$ interaction in $\mathbf{2}$ (Fig. 11). The phenyl rings adopt ' $\mathrm{Y}$ '- and ' $\mathrm{T}$ '-shaped edge-to-face arrangements (Martinez \& Iverson, 2012) with centroid-centroid distances of 5.019 (1)$5.738(1) \AA$ in $\mathbf{1}$ and $5.177(2)-5.961(2) \AA$ in 2 . Those

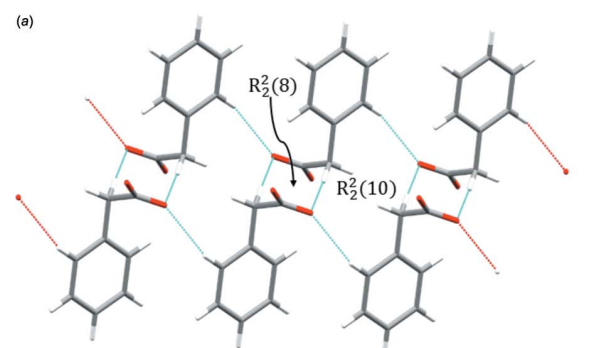

(b)

Figure 9

(a) The $\mathrm{C}-\mathrm{H} \cdots \mathrm{O}$ hydrogen-bonding pattern among the phenylacetate molecules in $\mathbf{1}$ consisting of alternating, fused $R_{2}^{2}(8)$ and $R_{2}^{2}(10)$ rings. (b) Discrete $\mathrm{C}-\mathrm{H} \cdots \mathrm{O}$ hydrogen bonds in $\mathbf{2}$. 


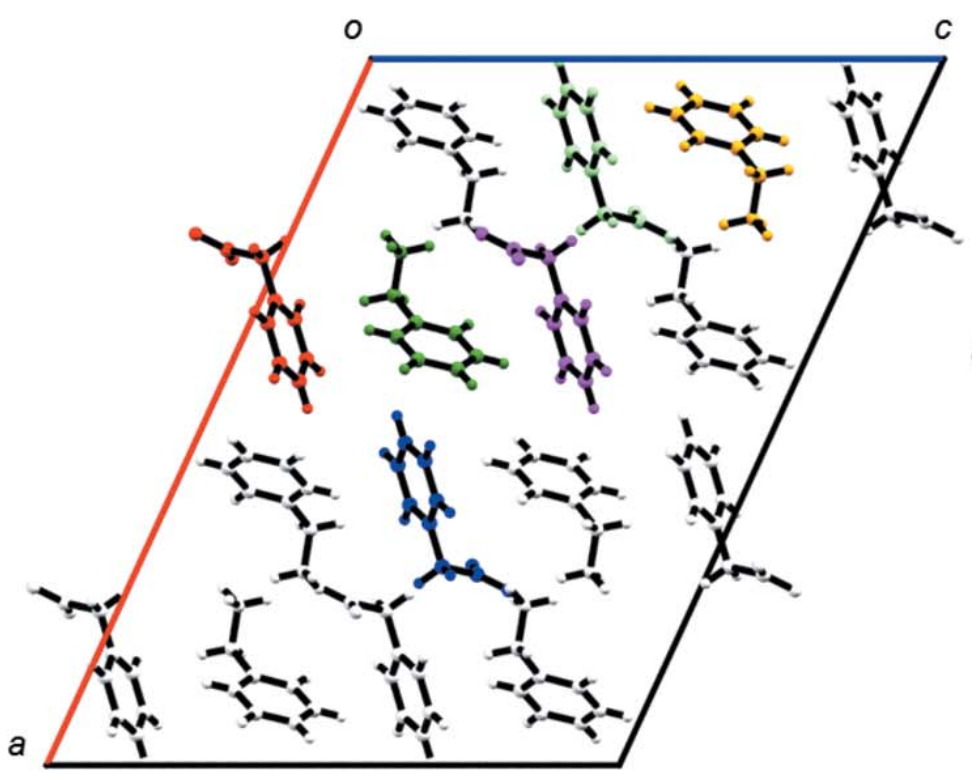

(a)
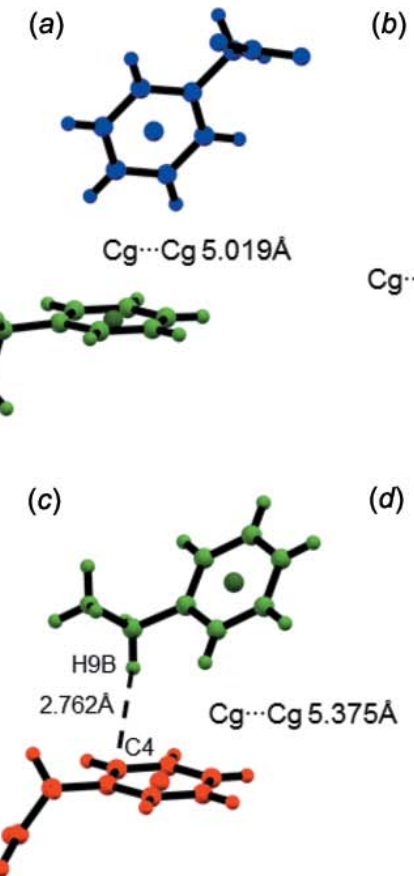

(b)

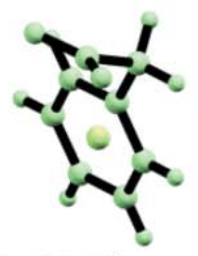

$\mathrm{Cg} \cdots \operatorname{Cg} 5.738 \AA$

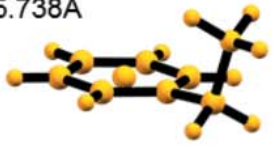

(d)

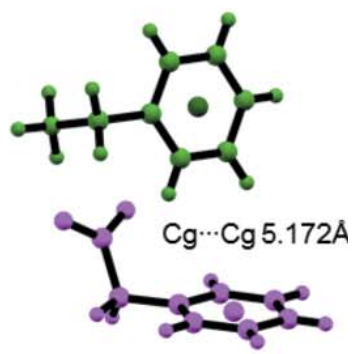

Figure 10

Short ring and aliphatic $\mathrm{C}-\mathrm{H} \cdots \pi$ interactions in $\mathbf{1}$.

distances are in the same range as the centroid-centroid distance observed in crystalline benzene (Klebe \& Diederich, 1993). Close H. .C contacts, i.e. smaller than the sum of the van der Waals radii (Bondi, 1964; Hu et al., 2014) of the two elements, are found as part of the aliphatic $\mathrm{C}-\mathrm{H} \cdots \pi$ interactions. In $\mathbf{1}$, the aliphatic $\mathrm{C}-\mathrm{H} \cdots \pi$ interaction is observed between benzylammonium (donor) and phenylacetate (acceptor), with the shortest distance being $2.762 \AA$ between

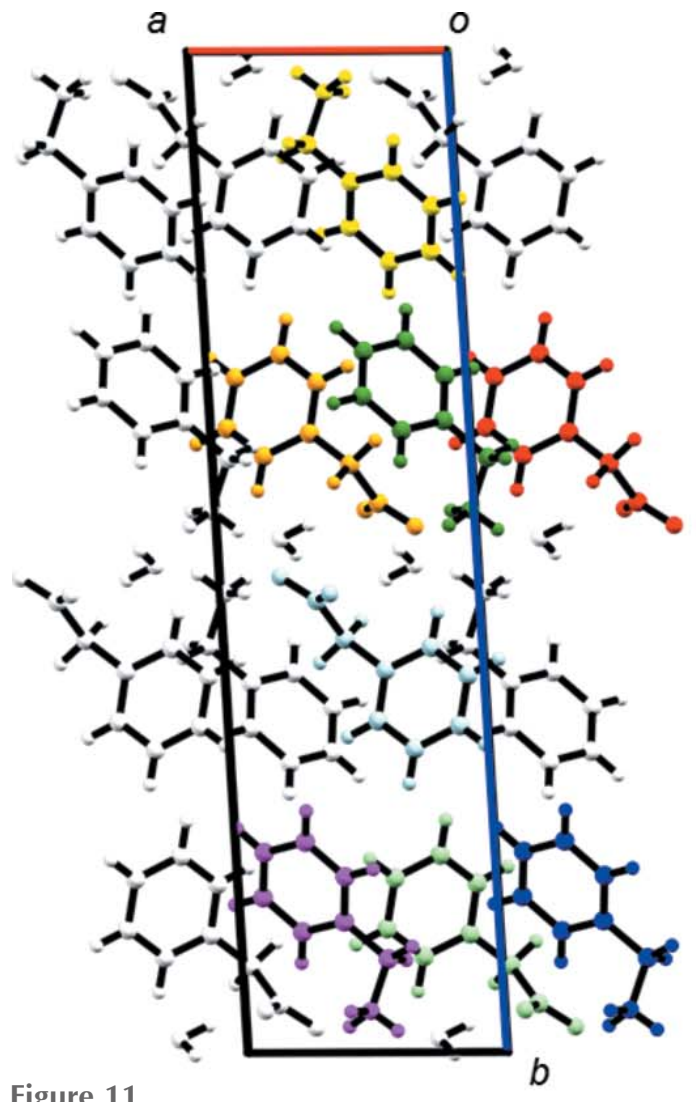

(a)

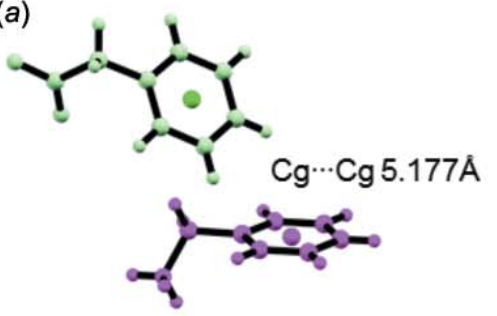

(c)

(e)
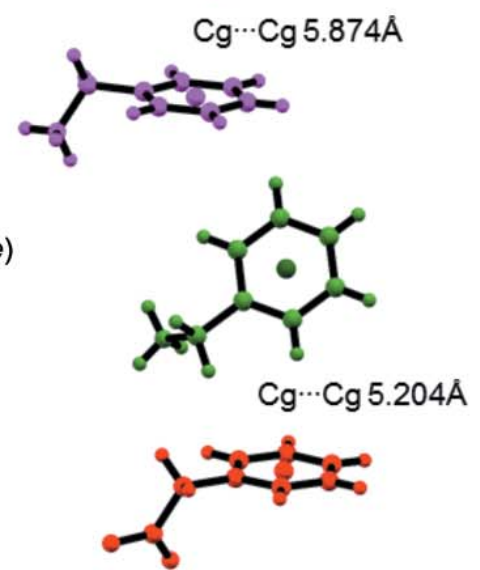

(b)

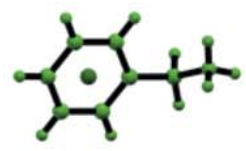

$$
\mathrm{Cg} \cdots \mathrm{Cg} 5.961 \AA
$$

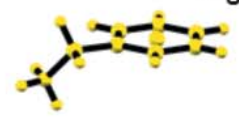

(d)

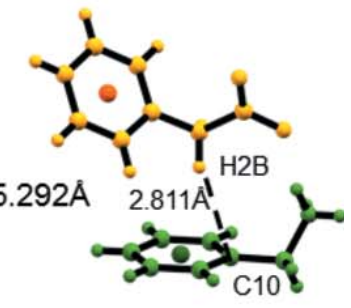

(f)

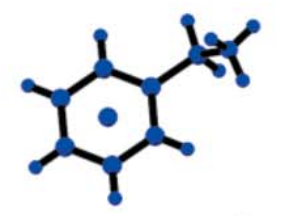

$\mathrm{Cg} \cdots \operatorname{Cg} 5.266 \AA$

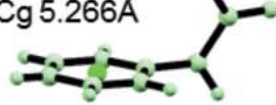

Short ring and aliphatic $\mathrm{C}-\mathrm{H} \cdots \pi$ interactions in $\mathbf{2}$. 
Table 4

Experimental details.

1

Crystal data

Chemical formula

$M_{\mathrm{r}}$

Crystal system, space group

Temperature (K)

$a, b, c(\AA)$

$\beta\left({ }^{\circ}\right)$

$V\left(\AA^{3}\right)$

$Z$

Radiation type

$\mu\left(\mathrm{mm}^{-1}\right)$

Crystal size (mm)

Data collection

Diffractometer

Absorption correction

$T_{\min }, T_{\max }$

No. of measured, independent and

observed $[I>2 \sigma(I)]$ reflections

$R_{\text {int }}$

$(\sin \theta / \lambda)_{\max }\left(\AA^{-1}\right)$

Refinement

$R\left[F^{2}>2 \sigma\left(F^{2}\right)\right], w R\left(F^{2}\right), S$

No. of reflections

No. of parameters

$\mathrm{H}$-atom treatment

$\Delta \rho_{\max }, \Delta \rho_{\min }\left(\mathrm{e} \AA^{-3}\right)$

\author{
$\mathrm{C}_{7} \mathrm{H}_{10} \mathrm{~N}^{+} \cdot \mathrm{C}_{8} \mathrm{H}_{7} \mathrm{O}_{2}{ }^{-}$ \\ 243.29 \\ Monoclinic, $C 2 / c$ \\ 100 \\ 25.913 (2), 5.9021 (5), 19.0842 (16) \\ $114.692(3)$ \\ 2651.9 (4) \\ 8 \\ Mo $K \alpha$ \\ 0.08 \\ $0.10 \times 0.04 \times 0.02$
}

2

Bruker D8 Venture TXS

Multi-scan (SADABS; Bruker,

2016)

$0.651,0.971$

14421, 2398, 1800

0.092

0.602

$\mathrm{C}_{7} \mathrm{H}_{10} \mathrm{~N}^{+} \cdot \mathrm{C}_{8} \mathrm{H}_{7} \mathrm{O}_{2}{ }^{-} \cdot \mathrm{H}_{2} \mathrm{O}$

261.31

Monoclinic, $P 2_{1} / n$

100

6.8235 (7), $7.8766(7), 26.364(2)$

$93.218(3)$

1414.7 (2)

4

Mo $K \alpha$

0.09

$0.10 \times 0.06 \times 0.04$

Bruker D8 Venture TXS

Multi-scan ( $S A D A B S$; Bruker, 2016)

$0.814,0.971$

7319, 2461, 2090

0.043

0.595

$0.043,0.103,1.03$
2398
175
$\mathrm{H}$ atoms treated by a mixture of
$\quad$ independent and constrained
$\quad$ refinement
$0.17,-0.23$

$0.075,0.170,1.25$

2461

187

$\mathrm{H}$ atoms treated by a mixture of independent and constrained refinement

$0.30,-0.27$

Computer programs: APEX3 and SAINT (Bruker, 2015), SHELXT (Sheldrick, 2015a), SHELXL2014/7 (Sheldrick, 2015b), ORTEP-3 for Windows (Farrugia, 2012), Mercury (Macrae et al., 2006), CrystalExplorer17 (Turner et al., 2017), PLATON (Spek, 2009) and RPLUTO (CCDC, 2018).

C9-H9B $\cdots \mathrm{C} 4$ (Fig. 10c). In 2, phenylacetate acts as a donor and benzlyammonium as an acceptor for the aliphatic $\mathrm{C}-$ $\mathrm{H} \cdots \pi$ interaction. The closest distance of $2.811 \AA$ is found between $\mathrm{C} 2-\mathrm{H} 2 B \cdots \mathrm{C} 10$ (Fig. 11d). Two more close contacts of the type $(\mathrm{C}-) \mathrm{H} \cdots \mathrm{C}$ can be identified in 2 via the $d_{\text {norm }^{-}}$ mapped Hirshfeld surfaces (see $H / H^{\prime}$ and $I / I^{\prime}$ in Fig. 6). In the first case, the carbon hydrogen distance $\mathrm{C} 5-\mathrm{H} 5 \cdots \mathrm{C} 1$ (2.812 $\AA$ ) between two phenylacetate molecules is just below the sum of the van der Waals distances. In the second case, the carbon hydrogen distance $\mathrm{C} 9-\mathrm{H} 9 A \cdots \mathrm{C} 4$ between benzylammonium and phenylacetate is $2.798 \AA$.

\section{Database survey}

A structure search on WebCSD (30.11.2018) resulted in 196 hits for structures including benzylammonium and 22 hits for structures including phenylacetate. Structures with packings closely related to those of $\mathbf{1}$ and $\mathbf{2}$ containing molecules similar to benzylammonium and phenylacetate can be found in Trivedi \& Dastidar (2006; CEKJEI, CEKJIM, CEKJOS), Olmstead et al. (2008; HOLDOC), Cai et al.. (2009; BUDQEX), Das et al. (2009; HUKJIH), Mahieux et al. (2012; FAHGIG), Tiritiris \& Kantlehner (2011; HOLDOC01) and Mossou et al. (2014; QQQAUJ03). For a more general view on ammonium carboxylate salts, see Odendal et al. (2010) who described the packing motifs in the crystal structures of such salts, and Kinbara et al. (1996) who described the role of hydrogen-bonded networks in the crystal structures of salts of chiral primary amines with achiral carboxylic acids.

\section{Synthesis and crystallization}

Benzylamine (185701), phenylacetic acid (P16621) and methanol (32213) were obtained from Sigma-Aldrich.

Benzylammonium phenylacetate (1) was obtained as follows. $40 \mathrm{mg}$ of phenylacetic acid $(0.29 \mathrm{mmol})$ were dissolved in $1 \mathrm{ml}$ of methanol and $32 \mu \mathrm{l}$ of benzylamine $(0.29 \mathrm{mmol})$ were added under gentle stirring. The solvent was then evaporated slowly under ambient conditions to yield colourless crystals of compound $\mathbf{1}$.

Benzylammonium phenylacetate hydrate (2) was obtained by dissolving $40 \mathrm{mg}$ of phenylacetic acid $(0.29 \mathrm{mmol})$ in $200 \mu \mathrm{l}$ of methanol and $32 \mu \mathrm{l}$ of benzylamine $(0.29 \mathrm{mmol})$ were added under gentle stirring. The solution was diluted with $1.8 \mathrm{ml}$ of ultra-pure water and evaporated slowly at ambient conditions to yield colourless crystals of compound $\mathbf{2}$.

\section{Refinement}

Crystal data, data collection and structure refinement details are summarized in Table 4. In $\mathbf{1}$ and $\mathbf{2}$, the C-bound hydrogen atoms were positioned with idealized coordinates $(\mathrm{C}-\mathrm{H}=$ 
0.95-0.99 ^) and refined as riding on their parent atoms with $U_{\text {iso }}(\mathrm{H})=1.2 U_{\text {eq }}(\mathrm{N} / \mathrm{O})$. The $\mathrm{N}$-bound hydrogen atoms in $\mathbf{1}$ were refined freely. In $\mathbf{2}$, the coordinates of the $\mathrm{N}$ - and $\mathrm{O}$ bound hydrogen atoms were freely refined while the isotropic displacement parameters of the hydrogen atoms were calculated as $U_{\text {iso }}(\mathrm{H})=1.2 U_{\mathrm{eq}}(\mathrm{N} / \mathrm{O})$.

\section{References}

Bernstein, J., Davis, R. E., Shimoni, L. \& Chang, N.-L. (1995). Angew. Chem. Int. Ed. Engl. 34, 1555-1573.

Bondi, A. (1964). J. Phys. Chem. 68, 441-451.

Bruker (2015). SAINT. Bruker AXS Inc., Madison, Wisconsin, USA. Bruker (2016). APEX3. Bruker AXS Inc., Madison, Wisconsin, USA.

Cai, Y.-J., Dai, X.-B., Liu, L., Li, J. \& Li, H.-Y. (2009). Acta Cryst. E65, o2341.

CCDC (2018). RPLUTO. Cambridge Crystallographic Data Centre, Cambridge, England.

Das, U. K., Trivedi, D. R., Adarsh, N. N. \& Dastidar, P. (2009). J. Org. Chem. 74, 7111-7121.

Do, T. D., Kincannon, W. M. \& Bowers, M. T. (2015). J. Am. Chem. Soc. 137, 10080-10083.

Eisenberg, D. \& Jucker, M. (2012). Cell, 148, 1188-1203.

Farrugia, L. J. (2012). J. Appl. Cryst. 45, 849-854.

Gazit, E. (2007). Chem. Soc. Rev. 36, 1263-1269.

Görbitz, C. H. (2010). Acta Cryst. B66, 84-93.

Hu, S.-Z., Zhou, Z.-H., Xie, Z.-X. \& Robertson, B. E. (2014). Z. Krist. Cryst. Mater. 229, 517-523.

Kinbara, K., Hashimoto, Y., Sukegawa, M., Nohira, H. \& Saigo, K. (1996). J. Am. Chem. Soc. 118, 3441-3449.

Klebe, G. \& Diederich, F. (1993). Philos. Trans. R. Soc. London Ser. $A, \mathbf{3 4 5}, 37-48$.
Macrae, C. F., Edgington, P. R., McCabe, P., Pidcock, E., Shields, G. P., Taylor, R., Towler, M. \& van de Streek, J. (2006). J. Appl. Cryst. 39, 453-457.

Mahieux, J., Gonella, S., Sanselme, M. \& Coquerel, G. (2012). CrystEngComm, 14, 103-111.

Manna, M. K., Rasale, D. B. \& Das, A. K. (2015). RSC Adv. 5, $90158-$ 90167.

Martinez, C. R. \& Iverson, B. L. (2012). Chem. Sci. 3, 2191-2201.

McKinnon, J. J., Jayatilaka, D. \& Spackman, M. A. (2007). Chem. Commun. pp. 3814-3816.

McManus, J. J., Charbonneau, P., Zaccarelli, E. \& Asherie, N. (2016). Curr. Opin. Colloid Interface Sci. 22, 73-79.

Mossou, E., Teixeira, S. C. M., Mitchell, E. P., Mason, S. A., AdlerAbramovich, L., Gazit, E. \& Forsyth, V. T. (2014). Acta Cryst. C70, 326-331.

Odendal, J. A., Bruce, J. C., Koch, K. R. \& Haynes, D. A. (2010). CrystEngComm, 12, 2398-2408.

Olmstead, M. M., Franco, J. U. \& Pham, D. (2008). Private Communication (Refcode HOLDOC). CCDC, Cambridge, England.

Ozbas, B., Rajagopal, K., Schneider, J. P. \& Pochan, D. J. (2004). Phys. Rev. Lett. 93, 268106.

Reches, M. \& Gazit, E. (2003). Science, 300, 625-627.

Sheldrick, G. M. (2015a). Acta Cryst. A71, 3-8.

Sheldrick, G. M. (2015b). Acta Cryst. C71, 3-8.

Spek, A. L. (2009). Acta Cryst. D65, 148-155.

Tiritiris, I. \& Kantlehner, W. (2011). Z. Naturforsch. B: Chem. Sci. 66, 164-176.

Trivedi, D. R. \& Dastidar, P. (2006). Chem. Mater. 18, 1470-1478.

Turner, M. J., McKinnon, J. J., Wolff, S. K., Grimwood, D. J., Spackman, P. R., Jayatilaka, D. \& Spackman, M. A. (2017). CrystalExplorer17. University of Western Australia, Australia. 


\section{supporting information}

Acta Cryst. (2019). E75, 194-201［https://doi.org/10.1107/S2056989019000288]

\section{The crystal structures of benzylammonium phenylacetate and its hydrate}

\section{David Hess and Peter Mayer}

\section{Computing details}

For both structures, data collection: APEX3 (Bruker, 2016); cell refinement: SAINT (Bruker, 2015); data reduction: SAINT (Bruker, 2015); program(s) used to solve structure: SHELXT (Sheldrick, 2015a); program(s) used to refine structure: SHELXL2014/7 (Sheldrick, 2015b); molecular graphics: ORTEP-3 for Windows (Farrugia, 2012), Mercury (Macrae et al., 2006), CrystalExplorer17 (Turner et al., 2017); software used to prepare material for publication: PLATON (Spek, 2009), RPLUTO (CCDC, 2018).

Benzylammonium phenylacetate (1)

\section{Crystal data}

$\mathrm{C}_{7} \mathrm{H}_{10} \mathrm{~N}^{+} \cdot \mathrm{C}_{8} \mathrm{H}_{7} \mathrm{O}_{2}^{-}$

$M_{r}=243.29$

Monoclinic, $C 2 / c$

$a=25.913(2) \AA$

$b=5.9021(5) \AA$

$c=19.0842(16) \AA$

$\beta=114.692(3)^{\circ}$

$V=2651.9(4) \AA^{3}$

$Z=8$

\section{Data collection}

Bruker D8 Venture TXS diffractometer

Radiation source: rotating anode (TXS), Bruker TXS

Focusing mirrors monochromator Detector resolution: 7.4074 pixels $\mathrm{mm}^{-1}$ mix of phi and $\omega$ scans Absorption correction: multi-scan

(SADABS; Bruker, 2016)

\section{Refinement}

Refinement on $F^{2}$

Least-squares matrix: full

$R\left[F^{2}>2 \sigma\left(F^{2}\right)\right]=0.043$

$w R\left(F^{2}\right)=0.103$

$S=1.03$

2398 reflections

175 parameters

0 restraints
$F(000)=1040$

$D_{\mathrm{x}}=1.219 \mathrm{Mg} \mathrm{m}^{-3}$

Mo $K \alpha$ radiation, $\lambda=0.71073 \AA$

Cell parameters from 4302 reflections

$\theta=3.5-25.4^{\circ}$

$\mu=0.08 \mathrm{~mm}^{-1}$

$T=100 \mathrm{~K}$

Block, colourless

$0.10 \times 0.04 \times 0.02 \mathrm{~mm}$

$T_{\min }=0.651, T_{\max }=0.971$

14421 measured reflections

2398 independent reflections

1800 reflections with $I>2 \sigma(I)$

$R_{\text {int }}=0.092$

$\theta_{\text {max }}=25.4^{\circ}, \theta_{\min }=3.3^{\circ}$

$h=-30 \rightarrow 30$

$k=-7 \rightarrow 7$

$l=-22 \rightarrow 22$

Hydrogen site location: mixed

$\mathrm{H}$ atoms treated by a mixture of independent and constrained refinement

$w=1 /\left[\sigma^{2}\left(F_{\mathrm{o}}^{2}\right)+(0.0352 P)^{2}+1.6577 P\right]$ where $P=\left(F_{\mathrm{o}}^{2}+2 F_{\mathrm{c}}^{2}\right) / 3$

$(\Delta / \sigma)_{\max }<0.001$

$\Delta \rho_{\max }=0.17 \mathrm{e} \AA^{-3}$

$\Delta \rho_{\min }=-0.22$ e $\AA^{-3}$ 


\section{Special details}

Geometry. All esds (except the esd in the dihedral angle between two 1.s. planes) are estimated using the full covariance matrix. The cell esds are taken into account individually in the estimation of esds in distances, angles and torsion angles; correlations between esds in cell parameters are only used when they are defined by crystal symmetry. An approximate (isotropic) treatment of cell esds is used for estimating esds involving l.s. planes.

Refinement. C-H: constr N-H: refall

Reflections affected by the beamstop or those of higher order and significant higher $\mathrm{Fo}^{2}$ than $\mathrm{Fc}^{2}$ (caused by X-ray mirror) have been omitted in the refinement.

Fractional atomic coordinates and isotropic or equivalent isotropic displacement parameters $\left(\AA^{2}\right)$

\begin{tabular}{|c|c|c|c|c|}
\hline & $x$ & $y$ & $z$ & $U_{\text {iso }} * / U_{\text {eq }}$ \\
\hline $\mathrm{O} 1$ & $0.28279(5)$ & -0.35459 (19) & $0.41706(7)$ & 0.0205 \\
\hline $\mathrm{O} 2$ & $0.24772(5)$ & $-0.07061(19)$ & $0.33362(7)$ & 0.0214 \\
\hline N1 & $0.27388(7)$ & $0.8748(3)$ & $0.20667(9)$ & $0.0204(4)$ \\
\hline H11 & $0.2496(9)$ & $0.977(4)$ & $0.1667(13)$ & $0.040(6)^{*}$ \\
\hline H12 & $0.2666(8)$ & $0.714(4)$ & $0.1867(12)$ & $0.035(6)^{*}$ \\
\hline H13 & $0.2661(10)$ & $0.883(4)$ & $0.2511(14)$ & $0.048(7)^{*}$ \\
\hline $\mathrm{C} 1$ & $0.27013(7)$ & $-0.1506(3)$ & $0.40169(10)$ & $0.0169(4)$ \\
\hline $\mathrm{C} 2$ & $0.28113(7)$ & $0.0118(3)$ & $0.46855(10)$ & 0.0190 \\
\hline $\mathrm{H} 2 \mathrm{~A}$ & 0.2687 & 0.1656 & 0.4476 & $0.023^{*}$ \\
\hline $\mathrm{H} 2 \mathrm{~B}$ & 0.2577 & -0.0353 & 0.4958 & $0.023^{*}$ \\
\hline $\mathrm{C} 3$ & $0.34259(7)$ & $0.0220(3)$ & $0.52591(10)$ & $0.0186(4)$ \\
\hline $\mathrm{C} 4$ & $0.36866(8)$ & $-0.1595(3)$ & $0.57485(10)$ & $0.0223(4)$ \\
\hline $\mathrm{H} 4$ & 0.3476 & -0.2937 & 0.5719 & $0.027^{*}$ \\
\hline $\mathrm{C} 5$ & $0.42493(8)$ & $-0.1460(3)$ & $0.62768(11)$ & $0.0266(4)$ \\
\hline H5 & 0.4421 & -0.2705 & 0.6608 & $0.032 *$ \\
\hline C6 & $0.45623(8)$ & $0.0480(3)$ & $0.63248(11)$ & $0.0307(5)$ \\
\hline H6 & 0.4948 & 0.0573 & 0.6688 & $0.037^{*}$ \\
\hline C7 & $0.43098(8)$ & $0.2279(3)$ & $0.58411(12)$ & $0.0321(5)$ \\
\hline $\mathrm{H} 7$ & 0.4523 & 0.3611 & 0.5869 & $0.038^{*}$ \\
\hline $\mathrm{C} 8$ & $0.37457(8)$ & $0.2153(3)$ & $0.53139(11)$ & 0.0255 \\
\hline $\mathrm{H} 8$ & 0.3576 & 0.3407 & 0.4986 & $0.031^{*}$ \\
\hline C9 & $0.33454(8)$ & $0.9379(3)$ & $0.22888(11)$ & $0.0273(5)$ \\
\hline H9A & 0.3411 & 1.0948 & 0.2491 & $0.033^{*}$ \\
\hline H9B & 0.3428 & 0.9326 & 0.1828 & $0.033^{*}$ \\
\hline $\mathrm{C} 10$ & $0.37371(7)$ & $0.7794(3)$ & $0.28918(10)$ & $0.0220(4)$ \\
\hline $\mathrm{C} 11$ & $0.38860(8)$ & $0.8179(3)$ & $0.36684(11)$ & $0.0281(5)$ \\
\hline H11A & 0.3763 & 0.9525 & 0.3826 & $0.034^{*}$ \\
\hline $\mathrm{C} 12$ & $0.42124(8)$ & $0.6622(4)$ & $0.42177(11)$ & 0.0354 \\
\hline $\mathrm{H} 12 \mathrm{~A}$ & 0.4310 & 0.6898 & 0.4748 & $0.042 *$ \\
\hline $\mathrm{C} 13$ & $0.43957(9)$ & $0.4672(4)$ & $0.39950(13)$ & $0.0375(5)$ \\
\hline H13A & 0.4614 & 0.3592 & 0.4371 & $0.045^{*}$ \\
\hline $\mathrm{C} 14$ & $0.42609(8)$ & $0.4292(3)$ & $0.32244(13)$ & $0.0357(5)$ \\
\hline H14 & 0.4394 & 0.2962 & 0.3072 & $0.043^{*}$ \\
\hline $\mathrm{C} 15$ & $0.39330(8)$ & $0.5841(3)$ & $0.26732(12)$ & $0.0296(5)$ \\
\hline H15 & 0.3841 & 0.5570 & 0.2144 & $0.035^{*}$ \\
\hline
\end{tabular}


Atomic displacement parameters $\left(\AA^{2}\right)$

\begin{tabular}{lllllll}
\hline & $U^{11}$ & $U^{22}$ & $U^{33}$ & $U^{12}$ & $U^{13}$ & $U^{23}$ \\
\hline O1 & $0.0266(7)$ & $0.0168(7)$ & $0.0177(6)$ & $0.0002(5)$ & $0.0089(5)$ & $0.0000(5)$ \\
O2 & $0.0305(7)$ & $0.0202(7)$ & $0.0134(6)$ & $0.0023(5)$ & $0.0091(5)$ & $0.0006(5)$ \\
N1 & $0.0279(9)$ & $0.0181(9)$ & $0.0150(8)$ & $0.0000(7)$ & $0.0089(7)$ & $0.0013(7)$ \\
C1 & $0.0161(9)$ & $0.0203(10)$ & $0.0168(9)$ & $-0.0024(7)$ & $0.0093(7)$ & $-0.0017(7)$ \\
C2 & $0.0233(10)$ & $0.0179(9)$ & $0.0177(9)$ & $0.0015(7)$ & $0.0104(8)$ & $0.0006(7)$ \\
C3 & $0.0246(10)$ & $0.0200(9)$ & $0.0152(9)$ & $0.0000(7)$ & $0.0122(8)$ & $-0.0030(7)$ \\
C4 & $0.0282(10)$ & $0.0225(10)$ & $0.0185(9)$ & $-0.0023(8)$ & $0.0119(8)$ & $-0.0019(7)$ \\
C5 & $0.0301(11)$ & $0.0271(10)$ & $0.0219(10)$ & $0.0060(8)$ & $0.0102(8)$ & $0.0001(8)$ \\
C6 & $0.0220(10)$ & $0.0371(12)$ & $0.0287(11)$ & $-0.0007(9)$ & $0.0064(9)$ & $-0.0081(9)$ \\
C7 & $0.0290(11)$ & $0.0275(11)$ & $0.0393(12)$ & $-0.0081(9)$ & $0.0140(10)$ & $-0.0062(9)$ \\
C8 & $0.0301(11)$ & $0.0197(10)$ & $0.0283(11)$ & $-0.0014(8)$ & $0.0138(9)$ & $-0.0005(8)$ \\
C9 & $0.0283(11)$ & $0.0274(11)$ & $0.0263(10)$ & $-0.0026(8)$ & $0.0116(9)$ & $0.0046(8)$ \\
C10 & $0.0200(10)$ & $0.0245(10)$ & $0.0232(10)$ & $-0.0038(7)$ & $0.0105(8)$ & $0.0019(8)$ \\
C11 & $0.0233(10)$ & $0.0377(12)$ & $0.0260(11)$ & $-0.0018(8)$ & $0.0128(9)$ & $-0.0017(9)$ \\
C12 & $0.0253(11)$ & $0.0591(15)$ & $0.0216(10)$ & $-0.0011(10)$ & $0.0097(9)$ & $0.0073(10)$ \\
C13 & $0.0219(11)$ & $0.0422(13)$ & $0.0402(13)$ & $0.0006(9)$ & $0.0051(10)$ & $0.0176(10)$ \\
C14 & $0.0222(11)$ & $0.0292(11)$ & $0.0481(14)$ & $0.0001(8)$ & $0.0073(10)$ & $-0.0029(10)$ \\
C15 & $0.0246(11)$ & $0.0318(11)$ & $0.0299(11)$ & $-0.0029(8)$ & $0.0090(9)$ & $-0.0037(9)$ \\
& & & & & &
\end{tabular}

Geometric parameters $\left(\AA,{ }^{\circ}\right)$

\begin{tabular}{llll}
\hline $\mathrm{O} 1-\mathrm{C} 1$ & $1.250(2)$ & $\mathrm{C} 7-\mathrm{C} 8$ & $1.388(3)$ \\
$\mathrm{O} 2-\mathrm{C} 1$ & $1.272(2)$ & $\mathrm{C} 7-\mathrm{H} 7$ & 0.9500 \\
$\mathrm{~N} 1-\mathrm{C} 9$ & $1.494(2)$ & $\mathrm{C} 8-\mathrm{H} 8$ & 0.9500 \\
$\mathrm{~N} 1-\mathrm{H} 11$ & $0.97(2)$ & $\mathrm{C} 9-\mathrm{C} 10$ & $1.501(3)$ \\
$\mathrm{N} 1-\mathrm{H} 12$ & $1.01(2)$ & $\mathrm{C} 9-\mathrm{H} 9 \mathrm{~A}$ & 0.9900 \\
$\mathrm{~N} 1-\mathrm{H} 13$ & $0.95(3)$ & $\mathrm{C} 9-\mathrm{H} 9 \mathrm{~B}$ & 0.9900 \\
$\mathrm{C} 1-\mathrm{C} 2$ & $1.525(2)$ & $\mathrm{C} 10-\mathrm{C} 11$ & $1.385(3)$ \\
$\mathrm{C} 2-\mathrm{C} 3$ & $1.511(2)$ & $\mathrm{C} 10-\mathrm{C} 15$ & $1.392(3)$ \\
$\mathrm{C} 2-\mathrm{H} 2 \mathrm{~A}$ & 0.9900 & $\mathrm{C} 11-\mathrm{C} 12$ & $1.385(3)$ \\
$\mathrm{C} 2-\mathrm{H} 2 \mathrm{~B}$ & 0.9900 & $\mathrm{C} 11-\mathrm{H} 11 \mathrm{~A}$ & 0.9500 \\
$\mathrm{C} 3-\mathrm{C} 8$ & $1.388(3)$ & $\mathrm{C} 12-\mathrm{C} 13$ & $1.378(3)$ \\
$\mathrm{C} 3-\mathrm{C} 4$ & $1.396(2)$ & $\mathrm{C} 12-\mathrm{H} 12 \mathrm{~A}$ & 0.9500 \\
$\mathrm{C} 4-\mathrm{C} 5$ & $1.386(3)$ & $\mathrm{C} 13-\mathrm{C} 14$ & $1.381(3)$ \\
$\mathrm{C} 4-\mathrm{H} 4$ & 0.9500 & $\mathrm{C} 13-\mathrm{H} 13 \mathrm{~A}$ & 0.9500 \\
$\mathrm{C} 5-\mathrm{C} 6$ & $1.384(3)$ & $\mathrm{C} 14-\mathrm{C} 15$ & $1.385(3)$ \\
$\mathrm{C} 5-\mathrm{H} 5$ & 0.9500 & $\mathrm{C} 14-\mathrm{H} 14$ & 0.9500 \\
$\mathrm{C} 6-\mathrm{C} 7$ & $1.379(3)$ & $\mathrm{C} 15-\mathrm{H} 15$ & 0.9500 \\
$\mathrm{C} 6-\mathrm{H} 6$ & 0.9500 & & 119.8 \\
& & & $120.88(18)$ \\
$\mathrm{C} 9-\mathrm{N} 1-\mathrm{H} 11$ & $109.1(13)$ & $\mathrm{C} 8-\mathrm{C} 7-\mathrm{H} 7$ & 119.6 \\
$\mathrm{C} 9-\mathrm{N} 1-\mathrm{H} 12$ & $110.4(11)$ & $\mathrm{C} 7-\mathrm{C} 8-\mathrm{C} 3$ & 119.6 \\
$\mathrm{H} 11-\mathrm{N} 1-\mathrm{H} 12$ & $109.2(17)$ & $\mathrm{C} 7-\mathrm{C} 8-\mathrm{H} 8$ & $110.87(15)$ \\
$\mathrm{C} 9-\mathrm{N} 1-\mathrm{H} 13$ & $109.0(14)$ & $\mathrm{C} 3-\mathrm{C} 8-\mathrm{H} 8$ &
\end{tabular}




\begin{tabular}{|c|c|}
\hline $\mathrm{H} 12-\mathrm{N} 1-\mathrm{H} 13$ & $107.9(17)$ \\
\hline $\mathrm{O} 1-\mathrm{C} 1-\mathrm{O} 2$ & $124.09(15)$ \\
\hline $\mathrm{O} 1-\mathrm{C} 1-\mathrm{C} 2$ & $118.04(15)$ \\
\hline $\mathrm{O} 2-\mathrm{C} 1-\mathrm{C} 2$ & $117.86(15)$ \\
\hline $\mathrm{C} 3-\mathrm{C} 2-\mathrm{C} 1$ & $113.80(14)$ \\
\hline $\mathrm{C} 3-\mathrm{C} 2-\mathrm{H} 2 \mathrm{~A}$ & 108.8 \\
\hline $\mathrm{C} 1-\mathrm{C} 2-\mathrm{H} 2 \mathrm{~A}$ & 108.8 \\
\hline $\mathrm{C} 3-\mathrm{C} 2-\mathrm{H} 2 \mathrm{~B}$ & 108.8 \\
\hline $\mathrm{C} 1-\mathrm{C} 2-\mathrm{H} 2 \mathrm{~B}$ & 108.8 \\
\hline $\mathrm{H} 2 \mathrm{~A}-\mathrm{C} 2-\mathrm{H} 2 \mathrm{~B}$ & 107.7 \\
\hline $\mathrm{C} 8-\mathrm{C} 3-\mathrm{C} 4$ & $118.27(17)$ \\
\hline $\mathrm{C} 8-\mathrm{C} 3-\mathrm{C} 2$ & $120.20(16)$ \\
\hline $\mathrm{C} 4-\mathrm{C} 3-\mathrm{C} 2$ & $121.53(16)$ \\
\hline $\mathrm{C} 5-\mathrm{C} 4-\mathrm{C} 3$ & $120.69(17)$ \\
\hline $\mathrm{C} 5-\mathrm{C} 4-\mathrm{H} 4$ & 119.7 \\
\hline $\mathrm{C} 3-\mathrm{C} 4-\mathrm{H} 4$ & 119.7 \\
\hline $\mathrm{C} 6-\mathrm{C} 5-\mathrm{C} 4$ & $120.34(18)$ \\
\hline $\mathrm{C} 6-\mathrm{C} 5-\mathrm{H} 5$ & 119.8 \\
\hline $\mathrm{C} 4-\mathrm{C} 5-\mathrm{H} 5$ & 119.8 \\
\hline $\mathrm{C} 7-\mathrm{C} 6-\mathrm{C} 5$ & $119.42(18)$ \\
\hline $\mathrm{C} 7-\mathrm{C} 6-\mathrm{H} 6$ & 120.3 \\
\hline $\mathrm{C} 5-\mathrm{C} 6-\mathrm{H} 6$ & 120.3 \\
\hline $\mathrm{C} 6-\mathrm{C} 7-\mathrm{C} 8$ & $120.39(18)$ \\
\hline $\mathrm{C} 6-\mathrm{C} 7-\mathrm{H} 7$ & 119.8 \\
\hline $\mathrm{O} 1-\mathrm{C} 1-\mathrm{C} 2-\mathrm{C} 3$ & $59.1(2)$ \\
\hline $\mathrm{O} 2-\mathrm{C} 1-\mathrm{C} 2-\mathrm{C} 3$ & $-122.12(17)$ \\
\hline $\mathrm{C} 1-\mathrm{C} 2-\mathrm{C} 3-\mathrm{C} 8$ & $110.26(18)$ \\
\hline $\mathrm{C} 1-\mathrm{C} 2-\mathrm{C} 3-\mathrm{C} 4$ & $-70.2(2)$ \\
\hline $\mathrm{C} 8-\mathrm{C} 3-\mathrm{C} 4-\mathrm{C} 5$ & $0.3(2)$ \\
\hline $\mathrm{C} 2-\mathrm{C} 3-\mathrm{C} 4-\mathrm{C} 5$ & $-179.29(16)$ \\
\hline $\mathrm{C} 3-\mathrm{C} 4-\mathrm{C} 5-\mathrm{C} 6$ & $-0.3(3)$ \\
\hline $\mathrm{C} 4-\mathrm{C} 5-\mathrm{C} 6-\mathrm{C} 7$ & $-0.1(3)$ \\
\hline $\mathrm{C} 5-\mathrm{C} 6-\mathrm{C} 7-\mathrm{C} 8$ & $0.4(3)$ \\
\hline $\mathrm{C} 6-\mathrm{C} 7-\mathrm{C} 8-\mathrm{C} 3$ & $-0.4(3)$ \\
\hline $\mathrm{C} 4-\mathrm{C} 3-\mathrm{C} 8-\mathrm{C} 7$ & $0.0(3)$ \\
\hline
\end{tabular}

$\begin{array}{ll}\text { N1-C9-H9A } & 109.5 \\ \text { C10-C9-H9A } & 109.5 \\ \text { N1-C9-H9B } & 109.5 \\ \text { C10-C9-H9B } & 109.5 \\ \text { H9A-C9-H9B } & 108.1 \\ \text { C11-C10-C15 } & 118.89(17) \\ \text { C11-C10-C9 } & 120.98(17) \\ \text { C15-C10-C9 } & 120.05(17) \\ \text { C12-C11-C10 } & 120.66(19) \\ \text { C12-C11-H11A } & 119.7 \\ \text { C10-C11-H11A } & 119.7 \\ \text { C13-C12-C11 } & 120.06(19) \\ \text { C13-C12-H12A } & 120.0 \\ \text { C11-C12-H12A } & 120.0 \\ \text { C12-C13-C14 } & 119.87(19) \\ \text { C12-C13-H13A } & 120.1 \\ \text { C14-C13-H13A } & 120.1 \\ \text { C13-C14-C15 } & 120.2(2) \\ \text { C13-C14-H14 } & 119.9 \\ \text { C15-C14-H14 } & 119.9 \\ \text { C14-C15-C10 } & 120.26(19) \\ \text { C14-C15-H15 } & 119.9 \\ \text { C10-C15-H15 } & 119.9 \\ & \end{array}$

$\mathrm{C} 2-\mathrm{C} 3-\mathrm{C} 8-\mathrm{C} 7 \quad 179.60(17)$

$\mathrm{N} 1-\mathrm{C} 9-\mathrm{C} 10-\mathrm{C} 11 \quad-86.5$ (2)

$\mathrm{N} 1-\mathrm{C} 9-\mathrm{C} 10-\mathrm{C} 15 \quad 90.2(2)$

$\mathrm{C} 15-\mathrm{C} 10-\mathrm{C} 11-\mathrm{C} 12 \quad-1.6(3)$

$\mathrm{C} 9-\mathrm{C} 10-\mathrm{C} 11-\mathrm{C} 12 \quad 175.07$ (17)

$\mathrm{C} 10-\mathrm{C} 11-\mathrm{C} 12-\mathrm{C} 13 \quad 0.4(3)$

$\mathrm{C} 11-\mathrm{C} 12-\mathrm{C} 13-\mathrm{C} 14 \quad 1.0(3)$

$\mathrm{C} 12-\mathrm{C} 13-\mathrm{C} 14-\mathrm{C} 15 \quad-1.3(3)$

$\mathrm{C} 13-\mathrm{C} 14-\mathrm{C} 15-\mathrm{C} 10 \quad 0.0$ (3)

$\mathrm{C} 11-\mathrm{C} 10-\mathrm{C} 15-\mathrm{C} 14 \quad 1.4(3)$

$\mathrm{C} 9-\mathrm{C} 10-\mathrm{C} 15-\mathrm{C} 14 \quad-175.34$ (18)

Hydrogen-bond geometry $\left(A,{ }^{\circ}\right)$

$C g 1$ is the centroid of the $\mathrm{C} 3-\mathrm{C} 8$ ring.

\begin{tabular}{lllll}
\hline$D-\mathrm{H} \cdots A$ & $D-\mathrm{H}$ & $\mathrm{H} \cdots A$ & $D \cdots A$ & $D-\mathrm{H} \cdots A$ \\
\hline $\mathrm{N} 1-\mathrm{H} 11 \cdots \mathrm{O} 1^{\mathrm{i}}$ & $0.97(2)$ & $1.77(2)$ & $2.7177(19)$ & $165(2)$ \\
$\mathrm{N} 1-\mathrm{H} 12 \cdots \mathrm{O} 2^{\mathrm{ii}}$ & $1.01(2)$ & $1.73(2)$ & $2.7306(19)$ & $170.1(18)$ \\
$\mathrm{N} 1-\mathrm{H} 13 \cdots \mathrm{O} 2^{\mathrm{iii}}$ & $0.95(3)$ & $1.85(3)$ & $2.7938(19)$ & $174(2)$ \\
$\mathrm{C} 2-\mathrm{H} 2 B \cdots 1^{\text {iv }}$ & 0.99 & 2.40 & $3.375(2)$ & 169
\end{tabular}




\begin{tabular}{lllll}
$\mathrm{C} 8-\mathrm{H} 8 \cdots \mathrm{O} 1^{\mathrm{iii}}$ & 0.95 & 2.63 & $3.539(2)$ & 161 \\
$\mathrm{C} 9-\mathrm{H} 9 \cdots \mathrm{Cg} 1^{\mathrm{v}}$ & 0.95 & 2.92 & $3.877(2)$ & 163 \\
\hline
\end{tabular}

Symmetry codes: (i) $-x+1 / 2, y+3 / 2,-z+1 / 2$; (ii) $-x+1 / 2, y+1 / 2,-z+1 / 2$; (iii) $x, y+1, z$; (iv) $-x+1 / 2,-y-1 / 2,-z+1$; (v) $x,-y+1, z-1 / 2$.

Benzylammonium phenylacetate (2)

Crystal data

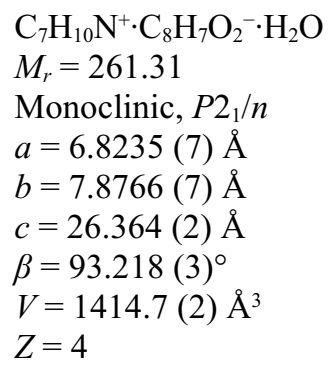

$F(000)=560$
$D_{\mathrm{x}}=1.227 \mathrm{Mg} \mathrm{m}^{-3}$

Mo $K \alpha$ radiation, $\lambda=0.71073 \AA$

Cell parameters from 4619 reflections

$\theta=2.7-25.0^{\circ}$

$\mu=0.09 \mathrm{~mm}^{-1}$

$T=100 \mathrm{~K}$

Block, colourless

$0.10 \times 0.06 \times 0.04 \mathrm{~mm}$

\section{Data collection}

Bruker D8 Venture TXS diffractometer

Radiation source: rotating anode (TXS), Bruker TXS

Focusing mirrors monochromator

Detector resolution: 7.4074 pixels $\mathrm{mm}^{-1}$

mix of phi and $\omega$ scans

Absorption correction: multi-scan

(SADABS; Bruker, 2016)

$$
\begin{aligned}
& T_{\min }=0.814, T_{\max }=0.971 \\
& 7319 \text { measured reflections } \\
& 2461 \text { independent reflections } \\
& 2090 \text { reflections with } I>2 \sigma(I) \\
& R_{\text {int }}=0.043 \\
& \theta_{\max }=25.0^{\circ}, \theta_{\min }=3.5^{\circ} \\
& h=-7 \rightarrow 7 \\
& k=-9 \rightarrow 8 \\
& l=-31 \rightarrow 27
\end{aligned}
$$$$
2090 \text { reflections with } I>2 \sigma(I)
$$

\section{Refinement}

Refinement on $F^{2}$

Least-squares matrix: full

$R\left[F^{2}>2 \sigma\left(F^{2}\right)\right]=0.075$

$w R\left(F^{2}\right)=0.170$

$S=1.25$

2461 reflections

187 parameters

0 restraints

Hydrogen site location: mixed

$\mathrm{H}$ atoms treated by a mixture of independent and constrained refinement

$$
w=1 /\left[\sigma^{2}\left(F_{\mathrm{o}}^{2}\right)+3.8665 P\right]
$$$$
\text { where } P=\left(F_{\mathrm{o}}^{2}+2 F_{\mathrm{c}}{ }^{2}\right) / 3
$$

$(\Delta / \sigma)_{\max }<0.001$

$\Delta \rho_{\max }=0.30$ e $\AA^{-3}$

$\Delta \rho_{\min }=-0.27$ e $\AA^{-3}$

Special details

Geometry. All esds (except the esd in the dihedral angle between two 1.s. planes) are estimated using the full covariance matrix. The cell esds are taken into account individually in the estimation of esds in distances, angles and torsion angles; correlations between esds in cell parameters are only used when they are defined by crystal symmetry. An approximate (isotropic) treatment of cell esds is used for estimating esds involving l.s. planes.

Refinement. C-H constr N-H and O-H: refxyz

Fractional atomic coordinates and isotropic or equivalent isotropic displacement parameters $\left(\AA^{2}\right)$

\begin{tabular}{lllll}
\hline & $x$ & $y$ & $z$ & $U_{\text {iso }} * U_{\text {eq }}$ \\
\hline O1 & $0.2350(3)$ & $0.5687(3)$ & $0.47484(9)$ & $0.0213(6)$ \\
O2 & $0.4238(4)$ & $0.7897(3)$ & $0.45801(10)$ & $0.0245(6)$ \\
O3 & $0.2403(4)$ & $0.0283(3)$ & $0.51346(10)$ & $0.0230(6)$ \\
H32 & $0.296(6)$ & $-0.048(6)$ & $0.4981(15)$ & $0.028^{*}$ \\
H31 & $0.355(6)$ & $0.089(5)$ & $0.5279(15)$ & $0.028^{*}$
\end{tabular}




$\begin{array}{lllll}\text { N1 } & 0.0153(5) & 0.2727(4) & 0.45885(12) & 0.0205(7) \\ \text { H11 } & 0.091(6) & 0.364(5) & 0.4595(14) & 0.025^{*} \\ \text { H12 } & -0.084(6) & 0.296(5) & 0.4786(15) & 0.025^{*} \\ \text { H13 } & 0.101(6) & 0.191(5) & 0.4742(14) & 0.025^{*} \\ \text { C1 } & 0.3709(5) & 0.6394(4) & 0.45153(13) & 0.0174(7) \\ \text { C2 } & 0.4705(5) & 0.5289(5) & 0.41280(13) & 0.0213(8) \\ \text { H2A } & 0.5366 & 0.4332 & 0.4311 & 0.026^{*} \\ \text { H2B } & 0.3676 & 0.4802 & 0.3892 & 0.026^{*} \\ \text { C3 } & 0.6199(5) & 0.6182(4) & 0.38174(13) & 0.0190(8) \\ \text { C4 } & 0.8017(5) & 0.6658(4) & 0.40418(14) & 0.0210(8) \\ \text { H4 } & 0.8333 & 0.6385 & 0.4388 & 0.025^{*} \\ \text { C5 } & 0.9377(5) & 0.7532(5) & 0.37627(14) & 0.0236(8) \\ \text { H5 } & 1.0604 & 0.7860 & 0.3921 & 0.028^{*} \\ \text { C6 } & 0.8942(6) & 0.7920(5) & 0.32577(14) & 0.0272(9) \\ \text { H6 } & 0.9862 & 0.8522 & 0.3069 & 0.033^{*} \\ \text { C7 } & 0.7154(6) & 0.7424(5) & 0.30294(14) & 0.0280(9) \\ \text { H7 } & 0.6851 & 0.7674 & 0.2681 & 0.034^{*} \\ \text { C8 } & 0.5802(5) & 0.6560(5) & 0.33093(14) & 0.0239(8) \\ \text { H8 } & 0.4583 & 0.6223 & 0.3149 & 0.029^{*} \\ \text { C9 } & -0.0635(5) & 0.2271(5) & 0.40676(13) & 0.0226(8) \\ \text { H9A } & -0.1605 & 0.3136 & 0.3947 & 0.027^{*} \\ \text { H9B } & -0.1320 & 0.1165 & 0.4080 & 0.027^{*} \\ \text { C10 } & 0.0974(5) & 0.2156(4) & 0.36952(13) & 0.0198(8) \\ \text { C11 } & 0.0829(6) & 0.3063(5) & 0.32460(14) & 0.0253(8) \\ \text { H11A } & -0.0272 & 0.3778 & 0.3174 & 0.030^{*} \\ \text { C12 } & 0.2285(6) & 0.2938(5) & 0.28976(14) & 0.0330(10) \\ \text { H12A } & 0.2175 & 0.3567 & 0.2590 & 0.040^{*} \\ \text { C13 } & 0.3896(6) & 0.1892(5) & 0.30013(15) & 0.0315(10) \\ \text { H13A } & 0.4887 & 0.1800 & 0.2764 & 0.038^{*} \\ \text { C14 } & 0.4056(6) & 0.0986(5) & 0.34496(14) & 0.0273(9) \\ \text { H14 } & 0.5164 & 0.0278 & 0.3521 & 0.033^{*} \\ \text { C15 } & 0.2608(5) & 0.1105(4) & 0.37956(14) & 0.0222(8) \\ \text { H15 } & 0.2722 & 0.0472 & 0.4102 & 0.027^{*} \\ & & & & \end{array}$

Atomic displacement parameters $\left(\AA^{2}\right)$

\begin{tabular}{lllllll}
\hline & $U^{11}$ & $U^{22}$ & $U^{33}$ & $U^{12}$ & $U^{13}$ & $U^{23}$ \\
\hline O1 & $0.0211(13)$ & $0.0190(13)$ & $0.0243(13)$ & $-0.0042(10)$ & $0.0064(10)$ & $-0.0027(11)$ \\
O2 & $0.0237(14)$ & $0.0181(13)$ & $0.0321(15)$ & $-0.0035(11)$ & $0.0068(10)$ & $-0.0066(12)$ \\
O3 & $0.0200(14)$ & $0.0212(14)$ & $0.0279(15)$ & $-0.0001(11)$ & $0.0032(10)$ & $-0.0061(12)$ \\
N1 & $0.0205(16)$ & $0.0160(16)$ & $0.0254(17)$ & $-0.0024(13)$ & $0.0050(13)$ & $-0.0044(14)$ \\
C1 & $0.0122(17)$ & $0.0197(18)$ & $0.0201(18)$ & $-0.0014(14)$ & $-0.0011(13)$ & $-0.0014(15)$ \\
C2 & $0.0248(19)$ & $0.0182(18)$ & $0.0213(19)$ & $-0.0018(15)$ & $0.0051(14)$ & $-0.0035(15)$ \\
C3 & $0.0200(18)$ & $0.0145(17)$ & $0.0229(19)$ & $0.0030(14)$ & $0.0052(14)$ & $-0.0045(15)$ \\
C4 & $0.0241(19)$ & $0.0192(18)$ & $0.0197(18)$ & $-0.0003(15)$ & $0.0020(14)$ & $-0.0012(15)$ \\
C5 & $0.0208(18)$ & $0.0188(19)$ & $0.031(2)$ & $0.0001(15)$ & $0.0034(15)$ & $-0.0036(16)$ \\
C6 & $0.029(2)$ & $0.025(2)$ & $0.029(2)$ & $-0.0042(17)$ & $0.0114(16)$ & $-0.0020(17)$ \\
C7 & $0.032(2)$ & $0.031(2)$ & $0.0213(19)$ & $0.0023(18)$ & $0.0045(15)$ & $0.0034(17)$
\end{tabular}




\begin{tabular}{lllllll}
\hline & & & & & \\
C8 & $0.0175(18)$ & $0.030(2)$ & $0.024(2)$ & $-0.0029(16)$ & $0.0018(14)$ & $-0.0048(17)$ \\
C9 & $0.0228(19)$ & $0.0222(19)$ & $0.0229(19)$ & $-0.0023(15)$ & $0.0019(14)$ & $-0.0030(16)$ \\
C10 & $0.0242(19)$ & $0.0157(17)$ & $0.0195(18)$ & $-0.0086(15)$ & $0.0026(14)$ & $-0.0055(15)$ \\
C11 & $0.030(2)$ & $0.025(2)$ & $0.0211(19)$ & $-0.0030(16)$ & $-0.0035(15)$ & $-0.0024(16)$ \\
C12 & $0.046(3)$ & $0.035(2)$ & $0.0176(19)$ & $-0.011(2)$ & $0.0033(17)$ & $0.0000(18)$ \\
C13 & $0.029(2)$ & $0.039(2)$ & $0.028(2)$ & $-0.0050(18)$ & $0.0110(16)$ & $-0.0072(19)$ \\
C14 & $0.028(2)$ & $0.025(2)$ & $0.029(2)$ & $-0.0025(16)$ & $0.0054(16)$ & $-0.0052(17)$ \\
C15 & $0.029(2)$ & $0.0142(17)$ & $0.0236(19)$ & $-0.0006(15)$ & $0.0046(15)$ & $-0.0017(15)$ \\
\hline
\end{tabular}

Geometric parameters $\left(\AA,{ }^{\circ}\right)$

\begin{tabular}{|c|c|c|c|}
\hline $\mathrm{O} 1-\mathrm{C} 1$ & $1.270(4)$ & $\mathrm{C} 6-\mathrm{H} 6$ & 0.9500 \\
\hline $\mathrm{O} 2-\mathrm{C} 1$ & $1.247(4)$ & $\mathrm{C} 7-\mathrm{C} 8$ & $1.391(5)$ \\
\hline $\mathrm{O} 3-\mathrm{H} 32$ & $0.83(4)$ & $\mathrm{C} 7-\mathrm{H} 7$ & 0.9500 \\
\hline $\mathrm{O} 3-\mathrm{H} 31$ & $0.97(4)$ & $\mathrm{C} 8-\mathrm{H} 8$ & 0.9500 \\
\hline N1—C9 & $1.490(4)$ & $\mathrm{C} 9-\mathrm{C} 10$ & $1.516(5)$ \\
\hline $\mathrm{N} 1-\mathrm{H} 11$ & $0.89(4)$ & C9-H9A & 0.9900 \\
\hline $\mathrm{N} 1-\mathrm{H} 12$ & $0.90(4)$ & $\mathrm{C} 9-\mathrm{H} 9 \mathrm{~B}$ & 0.9900 \\
\hline $\mathrm{N} 1-\mathrm{H} 13$ & $0.94(4)$ & $\mathrm{C} 10-\mathrm{C} 11$ & $1.382(5)$ \\
\hline $\mathrm{C} 1-\mathrm{C} 2$ & $1.529(5)$ & $\mathrm{C} 10-\mathrm{C} 15$ & $1.402(5)$ \\
\hline $\mathrm{C} 2-\mathrm{C} 3$ & $1.516(5)$ & $\mathrm{C} 11-\mathrm{C} 12$ & $1.394(5)$ \\
\hline $\mathrm{C} 2-\mathrm{H} 2 \mathrm{~A}$ & 0.9900 & $\mathrm{C} 11-\mathrm{H} 11 \mathrm{~A}$ & 0.9500 \\
\hline $\mathrm{C} 2-\mathrm{H} 2 \mathrm{~B}$ & 0.9900 & $\mathrm{C} 12-\mathrm{C} 13$ & $1.389(6)$ \\
\hline $\mathrm{C} 3-\mathrm{C} 8$ & $1.384(5)$ & $\mathrm{C} 12-\mathrm{H} 12 \mathrm{~A}$ & 0.9500 \\
\hline $\mathrm{C} 3-\mathrm{C} 4$ & $1.395(5)$ & $\mathrm{C} 13-\mathrm{C} 14$ & $1.380(6)$ \\
\hline $\mathrm{C} 4-\mathrm{C} 5$ & $1.398(5)$ & $\mathrm{C} 13-\mathrm{H} 13 \mathrm{~A}$ & 0.9500 \\
\hline $\mathrm{C} 4-\mathrm{H} 4$ & 0.9500 & $\mathrm{C} 14-\mathrm{C} 15$ & $1.385(5)$ \\
\hline $\mathrm{C} 5-\mathrm{C} 6$ & $1.382(5)$ & $\mathrm{C} 14-\mathrm{H} 14$ & 0.9500 \\
\hline $\mathrm{C} 5-\mathrm{H} 5$ & 0.9500 & $\mathrm{C} 15-\mathrm{H} 15$ & 0.9500 \\
\hline $\mathrm{C} 6-\mathrm{C} 7$ & $1.386(5)$ & & \\
\hline $\mathrm{H} 32-\mathrm{O} 3-\mathrm{H} 31$ & $100(4)$ & $\mathrm{C} 6-\mathrm{C} 7-\mathrm{H} 7$ & 120.0 \\
\hline $\mathrm{C} 9-\mathrm{N} 1-\mathrm{H} 11$ & $113(3)$ & $\mathrm{C} 8-\mathrm{C} 7-\mathrm{H} 7$ & 120.0 \\
\hline $\mathrm{C} 9-\mathrm{N} 1-\mathrm{H} 12$ & $110(2)$ & $\mathrm{C} 3-\mathrm{C} 8-\mathrm{C} 7$ & $121.3(3)$ \\
\hline $\mathrm{H} 11-\mathrm{N} 1-\mathrm{H} 12$ & $106(4)$ & $\mathrm{C} 3-\mathrm{C} 8-\mathrm{H} 8$ & 119.4 \\
\hline $\mathrm{C} 9-\mathrm{N} 1-\mathrm{H} 13$ & $114(2)$ & $\mathrm{C} 7-\mathrm{C} 8-\mathrm{H} 8$ & 119.4 \\
\hline $\mathrm{H} 11-\mathrm{N} 1-\mathrm{H} 13$ & $102(3)$ & $\mathrm{N} 1-\mathrm{C} 9-\mathrm{C} 10$ & $112.0(3)$ \\
\hline $\mathrm{H} 12-\mathrm{N} 1-\mathrm{H} 13$ & $111(3)$ & $\mathrm{N} 1-\mathrm{C} 9-\mathrm{H} 9 \mathrm{~A}$ & 109.2 \\
\hline $\mathrm{O} 2-\mathrm{C} 1-\mathrm{O} 1$ & $124.3(3)$ & $\mathrm{C} 10-\mathrm{C} 9-\mathrm{H} 9 \mathrm{~A}$ & 109.2 \\
\hline $\mathrm{O} 2-\mathrm{C} 1-\mathrm{C} 2$ & $119.7(3)$ & $\mathrm{N} 1-\mathrm{C} 9-\mathrm{H} 9 \mathrm{~B}$ & 109.2 \\
\hline $\mathrm{O} 1-\mathrm{C} 1-\mathrm{C} 2$ & $116.0(3)$ & $\mathrm{C} 10-\mathrm{C} 9-\mathrm{H} 9 \mathrm{~B}$ & 109.2 \\
\hline $\mathrm{C} 3-\mathrm{C} 2-\mathrm{C} 1$ & $115.7(3)$ & $\mathrm{H} 9 \mathrm{~A}-\mathrm{C} 9-\mathrm{H} 9 \mathrm{~B}$ & 107.9 \\
\hline $\mathrm{C} 3-\mathrm{C} 2-\mathrm{H} 2 \mathrm{~A}$ & 108.3 & $\mathrm{C} 11-\mathrm{C} 10-\mathrm{C} 15$ & $119.0(3)$ \\
\hline $\mathrm{C} 1-\mathrm{C} 2-\mathrm{H} 2 \mathrm{~A}$ & 108.3 & $\mathrm{C} 11-\mathrm{C} 10-\mathrm{C} 9$ & $120.3(3)$ \\
\hline $\mathrm{C} 3-\mathrm{C} 2-\mathrm{H} 2 \mathrm{~B}$ & 108.3 & $\mathrm{C} 15-\mathrm{C} 10-\mathrm{C} 9$ & $120.7(3)$ \\
\hline $\mathrm{C} 1-\mathrm{C} 2-\mathrm{H} 2 \mathrm{~B}$ & 108.3 & $\mathrm{C} 10-\mathrm{C} 11-\mathrm{C} 12$ & $120.6(4)$ \\
\hline $\mathrm{H} 2 \mathrm{~A}-\mathrm{C} 2-\mathrm{H} 2 \mathrm{~B}$ & 107.4 & $\mathrm{C} 10-\mathrm{C} 11-\mathrm{H} 11 \mathrm{~A}$ & 119.7 \\
\hline $\mathrm{C} 8-\mathrm{C} 3-\mathrm{C} 4$ & $118.3(3)$ & $\mathrm{C} 12-\mathrm{C} 11-\mathrm{H} 11 \mathrm{~A}$ & 119.7 \\
\hline
\end{tabular}




$\begin{array}{llll}\mathrm{C} 8-\mathrm{C} 3-\mathrm{C} 2 & 121.5(3) & \mathrm{C} 13-\mathrm{C} 12-\mathrm{C} 11 & 119.9(4) \\ \mathrm{C} 4-\mathrm{C} 3-\mathrm{C} 2 & 120.3(3) & \mathrm{C} 13-\mathrm{C} 12-\mathrm{H} 12 \mathrm{~A} & 120.1 \\ \mathrm{C} 3-\mathrm{C} 4-\mathrm{C} 5 & 120.7(3) & \mathrm{C} 11-\mathrm{C} 12-\mathrm{H} 12 \mathrm{~A} & 120.1 \\ \mathrm{C} 3-\mathrm{C} 4-\mathrm{H} 4 & 119.7 & \mathrm{C} 14-\mathrm{C} 13-\mathrm{C} 12 & 119.9(4) \\ \mathrm{C} 5-\mathrm{C} 4-\mathrm{H} 4 & 119.7 & \mathrm{C} 14-\mathrm{C} 13-\mathrm{H} 13 \mathrm{~A} & 120.0 \\ \mathrm{C} 6-\mathrm{C} 5-\mathrm{C} 4 & 120.2(3) & \mathrm{C} 12-\mathrm{C} 13-\mathrm{H} 13 \mathrm{~A} & 120.0 \\ \mathrm{C} 6-\mathrm{C} 5-\mathrm{H} 5 & 119.9 & \mathrm{C} 13-\mathrm{C} 14-\mathrm{C} 15 & 120.3(4) \\ \mathrm{C} 4-\mathrm{C} 5-\mathrm{H} 5 & 119.9 & \mathrm{C} 13-\mathrm{C} 14-\mathrm{H} 14 & 119.9 \\ \mathrm{C} 5-\mathrm{C} 6-\mathrm{C} 7 & 119.5(3) & \mathrm{C} 15-\mathrm{C} 14-\mathrm{H} 14 & 119.9 \\ \mathrm{C} 5-\mathrm{C} 6-\mathrm{H} 6 & 120.3 & \mathrm{C} 14-\mathrm{C} 15-\mathrm{C} 10 & 120.3(3) \\ \mathrm{C} 7-\mathrm{C} 6-\mathrm{H} 6 & 120.3 & \mathrm{C} 14-\mathrm{C} 15-\mathrm{H} 15 & 119.8 \\ \mathrm{C} 6-\mathrm{C} 7-\mathrm{C} 8 & 120.1(3) & \mathrm{C} 10-\mathrm{C} 15-\mathrm{H} 15 & 119.8 \\ & & & \\ \mathrm{O} 2-\mathrm{C} 1-\mathrm{C} 2-\mathrm{C} 3 & -4.5(5) & \mathrm{C} 6-\mathrm{C} 7-\mathrm{C} 8-\mathrm{C} 3 & 0.2(6) \\ \mathrm{O} 1-\mathrm{C} 1-\mathrm{C} 2-\mathrm{C} 3 & 174.7(3) & \mathrm{N} 1-\mathrm{C} 9-\mathrm{C} 10-\mathrm{C} 11 & -126.9(4) \\ \mathrm{C} 1-\mathrm{C} 2-\mathrm{C} 3-\mathrm{C} 8 & -107.2(4) & \mathrm{N} 1-\mathrm{C} 9-\mathrm{C} 10-\mathrm{C} 15 & 54.4(4) \\ \mathrm{C} 1-\mathrm{C} 2-\mathrm{C} 3-\mathrm{C} 4 & 72.2(4) & \mathrm{C} 15-\mathrm{C} 10-\mathrm{C} 11-\mathrm{C} 12 & 0.0(5) \\ \mathrm{C} 8-\mathrm{C} 3-\mathrm{C} 4-\mathrm{C} 5 & 1.6(5) & \mathrm{C} 9-\mathrm{C} 10-\mathrm{C} 11-\mathrm{C} 12 & -178.8(3) \\ \mathrm{C} 2-\mathrm{C} 3-\mathrm{C} 4-\mathrm{C} 5 & -177.8(3) & \mathrm{C} 10-\mathrm{C} 11-\mathrm{C} 12-\mathrm{C} 13 & 0.1(6) \\ \mathrm{C} 3-\mathrm{C} 4-\mathrm{C} 5-\mathrm{C} 6 & -0.7(5) & \mathrm{C} 11-\mathrm{C} 12-\mathrm{C} 13-\mathrm{C} 14 & -0.3(6) \\ \mathrm{C} 4-\mathrm{C} 5-\mathrm{C} 6-\mathrm{C} 7 & -0.5(6) & \mathrm{C} 12-\mathrm{C} 13-\mathrm{C} 14-\mathrm{C} 15 & 0.5(6) \\ \mathrm{C} 5-\mathrm{C} 6-\mathrm{C} 7-\mathrm{C} 8 & 0.8(6) & \mathrm{C} 13-\mathrm{C} 14-\mathrm{C} 15-\mathrm{C} 10 & -0.5(6) \\ \mathrm{C} 4-\mathrm{C} 3-\mathrm{C} 8-\mathrm{C} 7 & -1.4(5) & \mathrm{C} 11-\mathrm{C} 10-\mathrm{C} 15-\mathrm{C} 14 & 0.2(5) \\ \mathrm{C} 2-\mathrm{C} 3-\mathrm{C} 8-\mathrm{C} 7 & 178.1(3) & \mathrm{C} 9-\mathrm{C} 10-\mathrm{C} 15-\mathrm{C} 14 & 178.9(3) \\ & & & \end{array}$

Hydrogen-bond geometry $\left(\AA,{ }^{\circ}\right)$

\begin{tabular}{lllll}
\hline$D-\mathrm{H} \cdots A$ & $D-\mathrm{H}$ & $\mathrm{H} \cdots A$ & $D \cdots A$ & $D-\mathrm{H}^{\cdots} A$ \\
\hline $\mathrm{O} 3-\mathrm{H} 32 \cdots \mathrm{O} 2^{\mathrm{i}}$ & $0.83(4)$ & $1.90(4)$ & $2.728(4)$ & $175(4)$ \\
$\mathrm{O} 3-\mathrm{H} 31 \cdots \mathrm{O} 2^{\mathrm{ii}}$ & $0.97(4)$ & $1.81(4)$ & $2.771(4)$ & $169(3)$ \\
$\mathrm{N} 1-\mathrm{H} 11 \cdots \mathrm{O} 1$ & $0.89(4)$ & $1.92(4)$ & $2.791(4)$ & $168(4)$ \\
$\mathrm{N} 1-\mathrm{H} 12 \cdots \mathrm{O} 1^{\mathrm{iii}}$ & $0.90(4)$ & $1.96(4)$ & $2.805(4)$ & $157(4)$ \\
$\mathrm{N} 1-\mathrm{H} 13 \cdots \mathrm{O} 3$ & $0.94(4)$ & $1.87(4)$ & $2.809(4)$ & $170(3)$ \\
$\mathrm{C} 9-\mathrm{H} 9 B \cdots \mathrm{O} 3^{\text {iv }}$ & 0.99 & 2.51 & $3.196(4)$ & 126 \\
$\mathrm{C} 15-\mathrm{H} 15 \cdots \mathrm{O} 2^{\mathrm{i}}$ & 0.95 & 2.57 & $3.412(4)$ & 147
\end{tabular}

Symmetry codes: (i) $x, y-1, z$; (ii) $-x+1,-y+1,-z+1$; (iii) $-x,-y+1,-z+1$; (iv) $-x,-y,-z+1$. 